

\section{Sumário}

Editorial: ConstituCiOnalismo latino-AMERICANO: O QUE TEMOS EM COMUM? .15

Editorial: Constitucionalismo Latinoamericano: ¿Qué TENEMOS EN COMÚN? 17 Luís Roberto Barroso e Patrícia Perrone Campos Mello

Seção I: Poder Constituinte

As Constituições latino-AMERICANAS ENTRE A VIDA E A MORTE: POSSIBILIDADES E LIMITES DO PODER DE EMENDA

Luís Roberto Barroso e Aline Osorio

Criação constitucional sem Poder Constituinte: Os limites conceituais do poder de SUBSTITUIÇÃO OU REVISÃO DA CONSTITUIÇÃO

Carlos Bernal Pulido

Quem Conta Como naÇão? A ExClusão de temáticas LGBTI nas asSEMbleias CONSTituintes de Brasil e Colômbia

Rafael Carrano Lelis, Marcos Felipe Lopes de Almeida e Waleska Marcy Rosa

Em Defesa da PaRTicipaÇão: ANálise da iniciativa POPUlar Para alteraÇão da Constituição no Brasil E No EquAdor

Ilana Aló Cardoso Ribeiro e Lílian Márcia Balmant Emerique

Reflexões críticas sobre o Processo Constituinte Equatoriano de Montecristi (2007-2008)

E. Emiliano Maldonado

SeÇão II: Jurisdição Constitucional e Democracia

LA REVISIÓN JUDICIAL EN DEMOCRACIAS DEFECTUOSAS 154 Roberto Gargarella

Constituição E PluRalismo JURÍdico: A POSIÇÃo PARTICUlar do Brasil NO CONTEXTO LATINO-AMERICANO

Ana Paula Gonçalves Pereira de Barcellos

As CONSTITUiÇões LATINO-AMERICANAS PELAS LENTES DAS CORTES CONSTITUCiONAIS: A FORÇA NORMATIVA E O ROMANTISMO DOS PREÂMBULOS 185 Arnaldo Sampaio de Moraes Godoy e Carlos Frederico Santos 
REDES SOCIALES, JUSTICIA CONSTITUCIONAL Y DELIBERACIÓN PÚBLICA DE CALIDAD: LECCIONES DEL Plebiscito por la PAZ EN Colombia...........................................................203 Jorge Ernesto Roa Roa

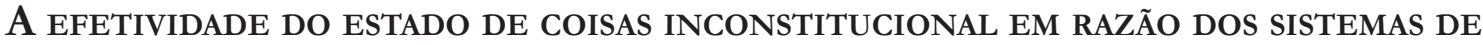
monitoramento: uma aNÁlise comparativa ENTRE Colômbia E Brasil 218

Aléssia Barroso Lima Brito Campos Chevitarese, Ana Borges Coêlho Santos e Felipe Meneses Graça

Seção III: Constitucionalismo Transformador e "Ius Constitucionale Commune" na AmÉRica LATina 231

O MANDATO TRANSFORMADOR DO Sistema INTERAMERICANO: LEgALIDADE E LEGITIMIDADE DE UM PROCESSO JURISGENÉTICO EXTRAORDINÁRIO 233 Armin von Bogdandy

CONSTITUCIONALISMO, TRANSFORMAÇÃO E RESILIÊNCIA DEMOCRÁTICA NO BRASIL: O IUS Constitucionale Commune na América Latina tem uma Contribuição a oferecer? .. 254 Patrícia Perrone Campos Mello

UM PROJETO COMUM PARA A AMÉRICA LATINA E OS IMPACTOS DAS EMPRESAS EM DIREITOS HUMANOS .287

Danielle Anne Pamplona

O papel da Corte Interamericana de Direitos humanos na construção dialogada do Ius Constitutionale Commune na América Latina..............................................303 Ana Carolina Lopes Olsen e Katya Kozicki

Seção IV: Novo Constitucionalismo Latino-Americano

O papel da Corte Interamericana de Direitos humanos na construÇão dialogada do Ius Constitutionale Commune na América Latina.................................................334 Roberto Viciano Pastor e Rubén Martínez Dalmau

¡Que viva El Estado Plurinacional!: ¿Y lo socioambiental? 351 Anibal Alejandro Rojas Hernández, aula Harumi Kanno, Heline Sivini Ferreira e Adriele Fernanda Andrade Précoma

O NOVO CONSTITUCIONALISMO LATINO-AMERICANO: ANÁLISE MARXISTA DA INVISIBILIZAÇÃO DA LUTA DE CLASSES NAS INVESTIGAÇÕES JURÍDICAS CRÍTICAS .365

Daniel Araújo Valença, Ronaldo Moreira Maia Júnior e Rayane Cristina de Andrade Gomes

O NOVO CONSTITUCIONALISMO LATINO-AMERICANO: ANÁLISE MARXISTA DA INVISIBILIZAÇÃO DA LUTA DE CLASSES NAS INVESTIGAÇÕES JURÍDICAS CRÍTICAS .382

Adriele Andrade Précoma, Heline Sivini Ferreira e Rogério Silva Portanova 
O direito À ÁGUA NAs Constituições da América do Sul: Elementos comuns e traços DISTINTIVOS.

Thiago Rafael Burckhart e Milena Petters Melo

Direitos Humanos na América Latina: avanços e desafios inerentes À atual CONJUNTURA POLÍTICA

Paulo Renato Vitória e Gabriela Maia Rebouças

O Novo Constitucionalismo na América latina e Caribe, e a construção do direito À SAÚDE

Alethele de Oliveira Santos, Maria Célia Delduque e Moacyr Rey Filho

A qualidade da educaÇão para a EFETIVaÇão E Consolidação do novo CONSTITUCIONALISMO LATINO-AMERICANO NO EQUADOR E NA BOLÍVIA.

Manuel Rodrigues de Sousa Junior e Luigi Bonizzato

A diversidade Cultural segundo o entendimento da Corte InTERAmericana de Direitos Humanos e o Novo Constitucionalismo Latino-Americano transformador. 476 Bianor Saraiva Nogueira Júnior, Deicy Yurley Parra Flórez e Ulisses Arjan Cruz dos Santos

UN APORTE A LA PROTECCIÓN DE LOS DERECHOS HUMANOS EN LATINOAMÉRICA: LA ACTIVIDAD del Ombudsman Criollo en tribunales de justicia 493 Juan Pablo Díaz Fuenzalida

SEÇÃo VI: Povos Indígenas

El DERECHO FUNDAMENTAL A LA IDENTIDAD CULTURAL DE LOS PUEBLOS INDÍGENAS: UN DERECHO-MATRIZ Y FILTRO HERMENÉUTICO PARA LAS CONSTITUCIONES DE AMÉRICA LATINA: LA JUSTIFICACIÓN 514 Juan Jorge Faundes

Povos INDígenas E A (AUSÊNCIA DE) JUSTIÇA DE TRANSIÇÃo BRASILEIRA: UMA ANÁLISE À LUZ DO CONSTITUCIONALISMO PLURALISTA LATINO-AMERICANO Jamilly Izabela de Brito Silva e Sílvia Maria da Silveira Loureiro

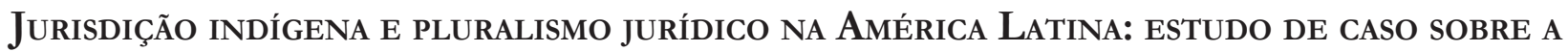
JUSTIÇA WAIWAI .558 João Vitor Cardoso e Luiz Guilherme Arcaro Conci

O NOVO CONSTITUCIONALISMO LATINO-AMERICANO E OS POVOS INDÍGENAS: A VisÃo Do DiREITO A PARTIR dOS CALEIDOSCÓPIOS E DOS MONÓCUlOS 577 Lucas Silva de Souza, Valéria Ribas do Nascimento e Isadora Forgiarini Balem 


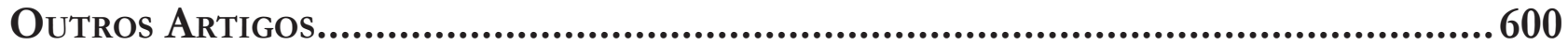

BUILDING TRUST IN COLLABORATIVE PROCESS OF VILLAGE FUND POLICY IMPLEMENTATION (A Case Study at Luwuk District of Banggai Regency) .........................................602 Rahmawati halim 


\title{
Quem conta como nação? A exclusão de temáticas LGBTI nas assembleias constituintes de Brasil e Colômbia*
}

\author{
Who counts as nation? The exclusion of \\ LGBTI issues in the constituent assembly of \\ Brazil and Colombia
}

\author{
Rafael Carrano Lelis** \\ Marcos Felipe Lopes de Almeida*** \\ Waleska Marcy Rosa****
}

\section{Resumo}

As Constituições do Brasil e da Colômbia não previram direitos LGBTI específicos, diferentemente de outras Constituições latino-americanas. Assim, tais direitos foram garantidos judicialmente. Esse fato gera questionamentos a respeito de como a nação foi representada no corpo constituinte. Nesse sentido, o objetivo do artigo é analisar os debates ocorridos nas Assembleias Constituintes brasileira e colombiana a respeito dos direitos LGBTI. Para isso, são analisadas as atas das sessões plenárias das Constituintes, sendo essa uma das limitações da investigação, uma vez que não foram analisadas todas as discussões que ocorreram nas referidas assembleias. Trata-se de pesquisa qualitativa, de caráter exploratório e com suporte na técnica de análise documental. Finalmente, constatou-se uma abordagem apenas incidental dos direitos LGBTI na Constituinte colombiana, com debates escassos, enquanto no Brasil houve uma maior discussão, marcada por argumentos negativos e positivos. A originalidade da pesquisa está na análise de dados pouco explorados pela comunidade acadêmica, sendo possível compreender como a população LGBTI foi representada e retratada no momento de elaboração do documento jurídico de mais alta hierarquia dos ordenamentos.

Palavras-chave: Direitos LGBTI. Orientação Sexual e Identidade de Gênero. Assembleia Nacional Constituinte do Brasil. Assembleia Nacional Constituinte da Colômbia. Heteronação. Novo Constitucionalismo Latinoamericano.

\section{Abstract}

The Constitutions of Brazil and Colombia did not include specific LGBTI rights, unlike other Latin American Constitutions. Thus, these rights were guaranteed through the judiciary. This fact raises questions about how the nation was represented in the constituent body. In this sense, the objective of this article is to analyze the debates that took place in the Brazilian and 
Colombian Constituent Assemblies regarding LGBTI rights. For this, the minutes of the plenary sessions of the Constituents are analyzed, being this one of the limitations of the investigation, since not all the discussions that took place in the assemblies were analyzed. It was conducted a qualitative research of exploratory character and supported by the documentary analysis technique. Finally, it was noted only incidental approach to LGBTI rights in the Colombian Constituent Assembly, with few debates, while in Brazil there was greater discussion, marked by negative and positive arguments. The originality of the research consists of the analysis of data yet little explored by the academic community, being possible to understand how the LGBTI population was represented and portrayed at the moment of elaboration of the legal document of the highest hierarchical importance.

Keywords: LGBTI Rights. Sexual Orientation and Gender Identity. National Constituent Assembly of Brazil. National Constituent Assembly of Colombia. Heteronation. New Latin-American Constitutionalism.

\section{Introdução}

As escolhas tomadas durante o processo de redação de uma nova Constituição são dependentes do perfil do grupo responsável pela sua criação. Dessa forma, quanto maior a diversidade entre os membros do corpo constituinte, maiores as chances de que a Constituição seja inclusiva perante as diversas realidades existentes dentro do país.

Com isso, grupos socialmente minoritários e marginalizados, como negros, mulheres, indígenas e pessoas LGBTI (Lésbicas, Gays, Bissexuais, Transgêneros e Intersexo), tendem a não ser contemplados adequadamente no texto constitucional, visto que, normalmente, ficam alijados do processo de sua elaboração.

Nesse sentido, a autora Ochy Curiel ${ }^{1}$ destaca, em especial na realidade latino-americana, a existência de uma heteronação (heteronación), de modo que a Constituição consiste em um contrato heterossexual no qual as categorias oprimidas em razão de gênero e de sexualidade não são devidamente representadas. Contudo, mesmo assim, pressupõe-se a sua aceitação para garantia da legitimidade do contrato.

No que se refere à previsão constitucional de direitos às pessoas LGBTI na América Latina, é necessário mencionar as Constituições da Bolívia e do Equador, que preveem, expressamente, a vedação à discriminação com base em orientação sexual e em identidade de gênero. Comumente, os referidos países são enquadrados no fenômeno do Novo Constitucionalismo Latino-Americano (NCLA). Entretanto, a inexistência de previsão constitucional não obsta o reconhecimento de direitos LGBTI, visto que estes podem ser garantidos judicialmente, como é o caso, principalmente, de Brasil e Colômbia.

Com base nisso, formula-se a seguinte pergunta de pesquisa: por que Brasil e Colômbia, os países mais avançados na jurisprudência constitucional sobre direitos LGBTI, não incorporaram direitos específicos nas suas respectivas Constituições? E, além disso, se chegaram a ser debatidos, como foram tratados os direitos da população LGBTI nas Assembleias Constituintes dos referidos países?

Dado o caráter exploratório da pesquisa, não serão formuladas hipóteses. No entanto, intenta-se, com os resultados do presente trabalho, a indicação de hipóteses para investigações futuras.

Assim, o objetivo geral é compreender e analisar as discussões promovidas no âmbito das Assembleias Constituintes do Brasil e da Colômbia no que tange à previsão de direitos LGBTI em seus textos constitucionais. Como objetivos específicos, apontam-se: delinear a ideia de nação heterossexual, relacionando-a com a ênfase dada à diversidade pelo Novo Constitucionalismo Latino-Americano; verificar a existência de discussões a respeito de direitos LGBTI nas atas das plenárias das Assembleias Constituintes brasileira e

CURIEL, Ochy. La nación heterosexual: análisis del discurso jurídico y el régimen heterosexual desde la antropología de la dominación. Bogotá: Impresol Ediciones, 2013. 
colombiana; categorizar os argumentos suscitados nos debates; e estabelecer conexões entre países a partir dos dados obtidos.

A justificativa para o presente trabalho reside na necessidade de compreender as dinâmicas presentes no processo de elaboração de uma nova Constituição, de modo a verificar quão inclusivas são determinadas escolhas tomadas pelo corpo constituinte. Com isso, é possível aferir a abrangência do conceito de nação incorporado no texto constitucional.

Finalmente, para o desenvolvimento da investigação proposta, o artigo será dividido em quatro partes, além da introdução e conclusão. Em um primeiro momento, elencam-se os aspectos atinentes ao marco teórico da heteronação, bem como as questões metodológicas necessárias para a concretização dos objetivos supracitados. Na sequência, será abordada a relação do Novo Constitucionalismo Latino-Americano com os direitos LGBTI. Posteriormente, a terceira e quarta seções tratam dos elementos empíricos referentes à Assembleia Constituinte brasileira e à colombiana, respectivamente.

\section{Aspectos teóricos e metodológicos}

Em sua obra La Nación Heterosexual, Ochy Curiel desenvolve a ideia daquilo que denominou de heteronación (heteronação), traçando sua teoria com base na análise do contexto de elaboração e promulgação da Constituição Colombiana de 1991. No entanto, como apontado pela própria autora, embora a investigação tenha se dado no cenário colombiano, "suas análises podem ser aplicadas a qualquer país da América Latina e do Caribe por terem processos parecidos na construção do Estado-nação"2. Nesse sentido, a autora conceitua a heteronação estabelecendo

como a nação e sua construção imaginária têm como base fundamental o regime da heterosexualidade, por meio da ideologia da diferença sexual, e esta, por sua vez, nas instituições como a família, o parentesco, a nacionalidade, tudo isso expresso nos pactos sociais que são refletidos em um texto normativo como a Constituição ${ }^{3}$.

Sendo assim, Curiel se baseia no aporte de teóricas feministas como Monique Wittig e Adrienne Rich para compreender o papel político exercido pelo "regime heterossexual"4 . Dialogando, também, com pensadores pós-coloniais, além de autores de correntes marxistas, valendo-se, principalmente, do conceito de hegemonia cunhado pelo italiano Antonio Gramsci ${ }^{5}$. Assim, a autora busca compreender qual a relação entre a heterossexualidade, enquanto instituição e regime político, e a construção da nação. Desse modo, ressalta a hegemonia heterossexual do processo constituinte e evidencia o já naturalizado caráter heterossexual "de um texto que pretende representar uma nação inteira " .

Desse modo, partindo da crítica realizada por $\mathrm{Wittig}^{7}$ à concepção do contrato social de Rousseau, a autora caracteriza a Constituição Política como sendo um contrato heterossexual, firmado com total ausên-

\footnotetext{
2 No original: "sus análisis puden ser aplicados a cualquier país de Latinoamerica y El Caribe, por tener processos parecidos em la construción del Estado-nación”. CURIEL, Ochy. La nación heterosexual: análisis del discurso jurídico y el régimen heterosexual desde la antropología de la dominación. Bogotá: Impresol Ediciones, 2013. p. 44, tradução nossa.

3 No original: "cómo la nación y su construcción imaginaria tienen como base fundamental el régimen de la heterosexualidad, a través de la ideología de la diferencia sexual, y ésta, a su vez, en las instituciones como la familia, al parentesco, a la nacionalidad, todo ello expresado en los pactos sociales que son reflejados en un texto normativo como la Constitución”. CURIEL, Ochy. La nación heterosexual: análisis del discurso jurídico y el régimen heterosexual desde la antropología de la dominación. Bogotá: Impresol Ediciones, 2013. p. 56, tradução nossa.

4 CURIEL, Ochy. La nación heterosexual: análisis del discurso jurídico y el régimen heterosexual desde la antropología de la dominación. Bogotá: Impresol Ediciones, 2013.

5 GRAMSCI, Antonio. El materialism histórico y la filosofia de Benedetto Croce. México: Juan Pablo Editor, 1975.

6 No original: "de un texto que pretende representar uma nación entera". CURIEL, Ochy. La nación heterosexual: análisis del discurso jurídico y el régimen heterosexual desde la antropología de la dominación. Bogotá: Impresol Ediciones, 2013. p. 38.

WITTIG, Monique. El pensamento heterosexual y otros ensayos. Barcelona: Egalesm, 2006.
} 
cia de representação de categorias oprimidas em virtude de gênero e sexualidade, mas que pressupõe sua aceitação para garantir legitimidade ao contrato. Nesse sentido, aponta que

a partir da análise de povo, de representação e das formas em que se fez este pacto social, que exige um significado de contrato simbólico, a partir da crítica que faz Monique Wittig ao contrato social de Rousseau, mostro como a Constituição Política de 1991, como lei suprema da nação, foi produto de um pacto entre as diferentes forças políticas partidárias, fundamentalmente constituídas por homens com privilégios de classe e raça, os quais, para além de suas diferenças políticas, coincidiram em garantir o caráter heterosssexual da nação, o que aqui chamarei de "um contrato heterossexual".

Dessa forma, a unidade da categoria imaginária de nação é forjada por grupos políticos hegemônicos em razão de gênero, classe, raça e sexualidade, apoiados no regime heterossexual, que estabelecem um pacto social que se propõe representativo de uma nação inteira, não obstante não tenha contado com a participação efetiva, entre outras, de mulheres e pessoas LGBTI. Nesse sentido, ainda que algumas mulheres tenham participado do processo constituinte (enquanto a ausência LGBTI era total), elas não possuíam as mesmas condições políticas que os homens de acordar e consentir com o referido contrato, uma vez que sua exclusão histórica e o machismo estrutural existente nas sociedades latino-americanas impediam sua paridade de participação, provocando o contentamento com previsões de direitos ainda impregnados da lógica do regime heterossexual'.

É importante frisar que, na lógica delineada por Curiel, o regime heterossexual sujeita não só as pessoas LGBTI, mas também as próprias mulheres não LGBTI, uma vez que tal regime se sustenta na diferenciação entre os gêneros, posicionando a mulher de forma subalterna em relação ao homem, dentro do relacionamento heterossexual. Desse modo, faz parte do referido regime a submissão da mulher, o que seria incompatível com sua atuação política na esfera pública, já que suas atividades somente seriam concebíveis no âmbito privado, voltadas à satisfação de seu marido ${ }^{10}$.

Sendo assim, não somente o pacto constituinte se caracteriza como uma ficção política, uma vez que pressupõe que todos os membros do grupo do povo e da nação estão de acordo com as normas estabelecidas, mas também a própria ideia de nação e do sujeito coletivo da nação se baseia em uma ilusão. Isso porque o sujeito coletivo já é construído de forma excludente, a partir da predominância dos grupos hegemônicos compostos por homens, brancos, heterossexuais e cisgêneros, enquanto os grupos dominados são tidos por representados independentemente de sua vontade. Nesse sentido, presume-se que as constituições são representativas de todo o povo e de toda a nação, quando na verdade se trata de um pacto firmado, apenas, entre grupos hegemônicos.

A partir disso, a autora questiona se, realmente, pode-se entender que houve consentimento ao texto constitucional dessa parcela da população, que teve um nível extremamente baixo (quando não inexistente) de participação. Desse modo, indaga, ainda, quem entraria na inteligibilidade de povo soberano ou de nação, a partir dos quais e em nome de quem foi promulgado o texto constituinte ${ }^{11}$. Assim, pergunta-se: as pessoas LGBTI, as mulheres e as pessoas não hegemonicamente racializadas contam como nação? Estariam elas

\footnotetext{
8 No original: "a partir del análisis de pueblo, de representación y de las formas en que se hizo este pacto social, que cobra un significado de contrato simbólico, desde la crítica que le hace Monique Wittig al contrato social de Rousseau, muestro cómo la Constitución Política de 1991, como ley suprema de la nación, fue producto de un pacto entre las diferentes fuerzas políticas partidarias, fundamentalmente constituidas por hombres con privilegios de clase y raza, quienes, más allá de sus diferencias políticas, coincidieron en garantizar un carácter heterosexual de la nación, lo que aquí llamaré 'un contrato heterosexual”'. CURIEL, Ochy. La nación heterosexual: análisis del discurso jurídico y el régimen heterosexual desde la antropología de la dominación. Bogotá: Impresol Ediciones, 2013. p. 42, tradução nossa.

9 CURIEL, Ochy. La nación heterosexual: análisis del discurso jurídico y el régimen heterosexual desde la antropología de la dominación. Bogotá: Impresol Ediciones, 2013.

10 CURIEL, Ochy. La nación heterosexual: análisis del discurso jurídico y el régimen heterosexual desde la antropología de la dominación. Bogotá: Impresol Ediciones, 2013.

11 CURIEL, Ochy. La nación heterosexual: análisis del discurso jurídico y el régimen heterosexual desde la antropología de la dominación. Bogotá: Impresol Ediciones, 2013.
} 
abarcadas pela ideia de povo soberano?

Dessa forma, o presente trabalho parte da ideia construída acima, que compreende o processo constituinte como o estabelecimento de um contrato heterossexual, que forja uma heteronação, para realizar a leitura das discussões relativas à inclusão de proteção contra a discriminação de pessoas LGBTI nas constituições do Brasil e da Colômbia. Ademais, adota-se, na análise dos textos, a abordagem descrita por Curiel como antropología da dominação (antropologia de la dominación), que "consiste em desvelar as formas, maneiras, estratégias, discursos que vão definindo certos grupos sociais como 'outros' e 'outras' a partir de lugares de poder e dominação" 12 . Nessa linha, diante da ausência de constituintes com identificação LGBTI, pretende-se analisar os discursos proferidos pelos parlamentares a partir da compreensão de que tais discursos são formas de construção das identidades LGBTI enquanto outros estranhos. E, justamente por isso, são discursos permeados pelo estabelecimento de estereótipos irreais e pela utilização de argumentos falaciosos no debate acerca da constitucionalização ou não da proteção de pessoas LGBTI.

Para tanto, após a coleta dos dados, que será descrita de forma detalhada nas seções que seguem, procedeu-se ao seu estudo por meio do método de análise qualitativa de documentação empírica proposto por Mario Cardano, que se divide em três etapas. São elas: segmentação, qualificação e individuação das relações. A segmentação se refere ao estabelecimento de marcadores, "cuja função consiste na identificação de segmentos relativamente homogêneos para submeter à comparação no interior dos materiais empíricos" 13 .

Mais adiante, a etapa da qualificação é conceituada por Cardano como a "atribuição de uma ou mais propriedades a um determinado segmento da documentação empírica, úteis à sua caracterização"14. Desse modo, a técnica permite que se aprofunde a dimensão de análise do documento por meio de sua maior especificação. Portanto, para a qualificação dos segmentos, utilizou-se a chamada template analysis, proposta por Nigel King ${ }^{15}$. O método consiste na composição de grades analíticas a partir da caracterização de cada uma das propriedades identificadas para possibilitar sua comparação. A utilização da template analysis pode se dar a partir de duas abordagens principais: indutiva, sendo a grade composta por meio do observado na análise do material, ou dedutiva, por meio da qual se encaixa o encontrado no documento analisado a categorias definidas previamente. $\mathrm{Na}$ presente pesquisa, adotou-se uma abordagem indutiva, estabelecendo-se as categorias de análises a partir do contato com os dados e as variáveis encontradas.

Por último, a individuação das relações consiste na análise a partir da comparação das qualificações. Ou, ainda, por meio da separação de determinada qualificação para análise. Sendo assim, nessa última etapa, realizou-se a análise por meio do exame cruzado das qualificações e, também, dos casos desviantes, destrinchando a sua distinção com relação aos demais.

Finalmente, é essencial destacar que este artigo descreve um estudo de direito constitucional comparado. Nesse sentido, conforme distinção apontada por Dário Moura Vicente, conduziu-se uma microcomparação ou comparação institucional ${ }^{16}$. Trata-se de hipótese na qual se investiga a abordagem dada por determinado ordenamento a um problema jurídico específico (nesse caso, a proteção de pessoas LGBTI na ordem constitucional), em contraste à possibilidade de exame das características gerais do sistema jurídico como um todo, quando se fala em macrocomparação. Por outro lado, no que diz respeito à metodologia de direito comparado, privilegiou-se aquela que busca compreender as causas de determinada situação jurídica, sendo aferida a partir do exame dos registros das assembleias constituintes de cada país.

\footnotetext{
12 No original: "consiste en develar las formas, maneras, estrategias, discursos que van definiendo a ciertos grupos sociales como 'otros' y 'otras' desde lugares de poder y dominación”. CURIEL, Ochy. La nación heterosexual: análisis del discurso jurídico y el régimen heterosexual desde la antropología de la dominación. Bogotá: Impresol Ediciones, 2013. p. 28, tradução nossa.

13 CARDANO, Mario. Manual de pesquisa qualitativa: a contribuição da teoria da argumentação. Petrópolis: Vozes, 2017. p. 273.

14 CARDANO, Mario. Manual de pesquisa qualitativa: a contribuição da teoria da argumentação. Petrópolis: Vozes, 2017. p. 293.

15 KING, Nigel. Doing template analysis. In: SYMON, Gillian; CASSEL, Catherine. Qualitative methods in organizational research: core methods and current challenges. London: Sage Publications, 2012. p. 426-450.

16 VICENTE, Dário Moura. Direito comparado. Coimbra: Almedina, 2016.
} 
Nesse sentido, seguindo o método comparativo, a observância de outras três etapas é imprescindível: “a) a delimitação do objeto da comparação a realizar; b) a análise dos termos a comparar; e c) a identificação, numa síntese comparativa, das semelhanças e diferenças entre esses termos e das respectivas causas" ${ }^{\prime 17}$. Sendo assim, delimitou-se a comparação definindo a análise das motivações da ausência de previsão constitucional expressa de direito específicos da população LGBTI, nos contextos constituintes de Brasil e Colômbia. Nesse sentido, os itens jurídicos a serem comparados se constituem a partir das discussões identificadas nos anais, referentes, especificamente, a questões ligadas à orientação sexual e à identidade de gênero.

Em sua proposta de adaptação do direito comparado tradicional à comparação constitucional, José Afonso da Silva frisa que o método comparatista deve seguir as fases de conhecimento, compreensão e comparação ${ }^{18}$. Em todas elas, destaca o proeminente papel ocupado pela análise contextual. Nesse sentido, descreve o que chama de hermenêutica contextual "que se refere à exploração da influência do contexto sobre o sentido da Constituição" 19 . Assim, identifica a importância do contexto enquanto fator externo (extratexto) essencial à compreensão das normas constitucionais. Nesta investigação, o contexto tem especial relevância, considerando a tentativa de determinação das causas da exclusão de direitos e não de sua previsão.

\section{Direitos LGBTI no novo constitucionalismo latino-americano}

O fenômeno do Novo Constitucionalismo Latino-Americano representa uma transformação constitucional sem precedentes na região. Nesse sentido, é importante sua diferenciação do chamado neoconstitucionalismo. Isso porque, enquanto o neoconstitucionalismo expressa uma corrente doutrinária de teoria do direito (mais do que de teoria da constituição), o NCLA se materializou fora do ambiente acadêmico, partindo da reivindicação dos movimentos sociais ${ }^{20}$. Também, por isso, as assembleias constituintes presenciaram debates sobre questões antes ignoradas pelas casas legislativas e diplomas normativos da região, principalmente no plano constitucional. Em virtude disso, alguns autores apontam a preocupação com a legitimidade democrática na construção constitucional como uma das principais características do NCLA ${ }^{21}$.

Não obstante, conforme destacado anteriormente, essa legitimidade encontrou sérios limites, principalmente no que se refere a uma representação efetiva, que supere as amarras impostas pelo regime heterossexual. De fato, é possível se identificar uma melhora progressiva no que diz respeito à participação popular e à efetiva legitimidade dos processos constituintes, quando bem observados os distintos países latino-americanos. É também por esse motivo que, embora se reconheça, sem grandes dificuldades, Bolívia e Equador como os maiores representantes do referido movimento, há grandes divergências no que diz respeito ao marco inicial do novo constitucionalismo.

Nesse sentido, Pastor e Dalmau entendem que a Constituição Brasileira de 1988 somente poderia ser caracterizada como neoconstitucionalista, devido a certa carência de legitimidade democrática no processo constituinte, em virtude da ainda forte influência de parlamentares ligados aos regimes ditatoriais prece-

\footnotetext{
VICENTE, Dário Moura. Direito comparado. Coimbra: Almedina, 2016. p. 38-39.

1 SILVA, José Afonso da. Um pouco de direito constitucional comparado. São Paulo: Malheiros, 2009.

19 SILVA, José Afonso da. Um pouco de direito constitucional comparado. São Paulo: Malheiros, 2009. p. 41.

20 PASTOR, Roberto Viciano; DALMAU, Rubén Martínez. ¿Se puede bablar de un nuevo constitucionalismo latinoamericano como corriente doctrinal sistematizada? Valencia: Universidad de Valencia, 2010.

21 Nesse sentido, ver: VIEIRA, José Ribas et al. Impasses e alternativas em 200 anos de constitucionalismo latino-americano. Revista de Estudos Constitucionais, Hermenêutica e Teoria do Direito (RECHTD), São Leopoldo, v. 5, n. 2, p. 122-132, jul./dez. 2013. PASTOR, Roberto Viciano; DALMAU, Rubén Martínez. ¿ Se puede hablar de un nuevo constitucionalismo latinoamericano como corriente doctrinal siste- matizada? Valencia: Universidad de Valencia, 2010. TEIXEIRA, João Paulo Allain. Direitos fundamentais e constituição: as respostas do neoconstitucionalismo europeu e do novo constitucionalismo latino-americano. In: SANTOS, Gustavo Ferreira; STRECK, Lenio Luiz; ARAÚJO, Marcelo Labanca Corrêa de (orgs.). Direitos e democracia no novo constitucionalismo latino-americano. Belo Horizonte: Arraes Editores, 2016. p. 45-51. SANTOS, Boaventura de Souza. Refundación del Estado en América Latina: perspectivas desde una epistemología del sur. Lima: Instituto Internacional de Derecho y Sociedad, 2010.
} 
dentes. Sendo assim, apontam, de modo mais incisivo, as experiências de Colômbia, Venezuela, Bolívia e Equador como sendo aquelas integrantes do $\mathrm{NCLA}^{22}$.

Por outro lado, há diversos autores que consideram a Constituição Brasileira como o marco inicial que teria dado origem ao que hoje se identifica como NCLA. Nessa linha, destacam que, embora não haja coincidência integral de algumas das características mais despojadas observadas nas constituições posteriores, a Carta brasileira possui suficientes elementos de ruptura com a tradição constitucional anterior para que seja compreendida dentro de um novo movimento, sobretudo no que diz respeito à significativa expansão de direitos ${ }^{23}$.

A esse respeito, esta investigação adota a perspectiva dos ciclos constitucionais, proposta por Raquel Yrigoyen Fajardo ${ }^{24}$. Estabelecendo como ponto de partida a garantia de direitos aos povos indígenas e o reconhecimento da diversidade cultural, a autora estabelece três diferentes ciclos constitucionais nos quais enquadra as recentes transformações no cenário latino-americano. O primeiro ciclo se refere ao chamado constitucionalismo multicultural e está compreendido entre os anos de 1982-1988. Nessa categoria, dentre os países latinos, estariam as constituições da Nicarágua, Guatemala e Brasil. Sua característica principal seria a emergência de novas demandas indígenas e sua consequente inclusão no texto constitucional, juntamente ao reconhecimento da diversidade cultural e ao estabelecimento de direitos indígenas específicos.

Por sua vez, o segundo ciclo, o do constitucionalismo pluricultural, abarca os anos de 1989-2005, englobando os textos constitucionais de Colômbia, México (reforma de 1992), Paraguai, Perú, Bolívia (de 1994 e 2004), Argentina (reforma de 1994), Equador (de 1998) e Venezuela. Nessa segunda classificação, a inserção de nação multiétnica e multicultural, bem como a redefinição do caráter do Estado (reconhecendo-o como pluricultural), somam-se às características apontadas com relação ao ciclo anterior.

Por último, tem-se o ciclo do constitucionalismo plurinacional, do período de 2006-2009, representado pelas constituições do Equador de 2008 e da Bolívia de 2009. Nesse último ciclo, observa-se uma ruptura mais radical e transformadora. Desse modo, ele é marcado pelo reconhecimento dos povos indígenas enquanto "nações originárias ou nações com autodeterminação ou livre determinação" 25. Assim, os povos indígenas recuperam seu poder de autogoverno, reconhecido agora pelo próprio Estado, a partir da refundação do Estado como um pacto entre diferentes povos.

Desse modo, consideramos não somente a Constituição Colombiana, mas também a brasileira como integrante da corrente do novo constitucionalismo. Assim, compreende-se que a investigação conduzida se refere à identificação de características em comum do NCLA.

22 PASTOR, Roberto Viciano; DALMAU, Rubén Martínez. Los procesos constituyentes latinoamericanos y el nuevo paradigma constitucional. Revista del Instituto de Ciencias Jurídicas de Puebla, Puebla, v. 25, p. 7-29, 2010. PASTOR, Roberto Viciano; DALMAU, Rubén Martínez. ¿Se puede hablar de un nuevo constitucionalismo latinoamericano como corriente doctrinal siste- matizada? Valencia: Universidad de Valencia, 2010. PASTOR, Roberto Viciano; DALMAU, Rubén Martínez. Presentación: aspectos generales del nuevo constitucionalismo latinoamericano. In: CORTE CONSTITUCIONAL DE ECUADOR PARA EL PERÍODO DE TRANSICIÓN. El nuevo constitucionalismo en América Latina: memorias del encuentro internacional El nuevo constitucionalismo: desafíos y retos para el siglo XXI. Quito: Corte Constitucional del Ecuador, 2010. p. 09-44. PASTOR, Roberto Viciano; DALMAU, Rubén Martínez. Fundamentos teóricos y prácticos del nuevo constitucionalismo latinoamericano. Gaceta Constitucional, v. 48, p. 307-328, 2011.

23 AVRITZER, Leonardo. O novo constitucionalismo latino-americano: uma abordagem política. In: AVRITZER, Leonardo et al. O constitucionalismo democrático latino-americano em debate: soberania, separação de poderes e sistema de direitos. Belo Horizonte: Autêntica, 2017. p. 19-42. MAGALHÃES, José Luiz Quadros de. O novo constitucionalismo democrático na América Latina. Revista Vox, Reduto, v. 01, p. 01-14, jan./jun. 2015.

24 FAJARDO, Raquel Z. Yrigoyen. El horizonte del constitucionalismo pluralista: del multiculturalismo a la decolonización. In: GARAVITO, César Rodríguez (coord.). El derecho en América Latina: un mapa para el pensamento jurídico del siglo XXI. Buenos Aires: Siglo Veintiuno Editores, 2011. p. 139-159.

25 No original: "naciones originarias o nacionalidades con autodeterminación o libre determinación”. FAJARDO, Raquel Z. Yrigoyen. El horizonte del constitucionalismo pluralista: del multiculturalismo a la decolonización. In: GARAVITO, César Rodríguez (coord.). El derecho en América Latina: un mapa para el pensamento jurídico del siglo XXI. Buenos Aires: Siglo Veintiuno Editores, 2011. p. 139-159. p. 9, tradução nossa. 
Superadas as divergências de categorização e identificada a referência de classificação das constituições, é importante a identificação da relação entre o NCLA e a proteção das pessoas LGBTI. Como um todo, diversas são as características apontadas do NCLA. Em síntese geral de atributos mais específicos, Leonardo Avritzer destaca o exercício de um novo papel pelo poder judiciário; a ampliação das formas de participação, sobretudo a partir de mecanismos democráticos de participação popular direta e indireta; e a grande ampliação de direitos previstos no texto constitucional, com destaque para aqueles de grupos historicamente oprimidos e que não encontravam tutela do ordenamento jurídico ${ }^{26}$.

Essa expansão dos direitos é, sem dúvida, um dos traços que possuiria maior potencial de atingir, positivamente, a população LGBTI. Isso porque assim se estabilizou a garantia e o status de sujeito de direito a outras identidades subalternas da região, como mulheres, negros e indígenas. Nesse sentido, Streck e Oliveira ressaltam que se tratam de constituições "com alta carga inovadora, rompendo padrões arraigados, emancipadoras de povos tradicionalmente oprimidos, postos à margem do debate público"27. Embora a mera ampliação de direitos não baste para a alteração estrutural do cenário de desigualdades, sendo necessária uma profunda reforma das instituições liberais que foram mantidas praticamente intactas nas alterações constitucionais promovidas, como aponta Gargarella ${ }^{28}$, tal ampliação não deve ser menosprezada. Desse modo, é importante a identificação dos direitos LGBTI nessa ampliação no contexto latino-americano.

Nesse sentido, é comum que se aponte e valorize o marco da diversidade nas constituições do NCLA ${ }^{29}$, ou, ainda, a ampliação do conceito de cidadania nessas novas conformações constitucionais ${ }^{30}$. Todavia, tanto a diversidade quanto a ampliação da cidadania continuam atuando de forma limitada no novo constitucionalismo, encontrando, na tutela das pessoas LGBTI, uma de suas principais barreiras. Principalmente amparadas no regime heterossexual, as subversões de gênero e sexualidade ainda se mostram como tabus quase intransponíveis aos poderes hegemônicos constituintes.

A respeito disso, destaca-se que apenas as constituições de Equador e Bolívia possuem previsão de direito específico de pessoas LGBTI desde sua promulgação, enquanto a Constituição Mexicana passou a contar com uma menção, adicionada por emenda no ano de 2011. Sob essa perspectiva, Equador e Bolívia apresentam vedação expressa à discriminação com base em orientação sexual e em identidade de gênero. Por outro lado, a carta mexicana pró́be o tratamento discriminatório motivado por "preferências sexuais". Ademais, o texto boliviano consagra a garantia do exercício de direitos sexuais e reprodutivos. Por fim, a Constituição equatoriana ainda prevê a tutela do direito de "escolha" livre e segura da orientação sexual, além de impor o dever de respeito e reconhecimento pelos equatorianos da orientação e identidade sexual e de assegurar a liberdade estética. Os demais textos não possuem qualquer previsão de direitos específicos a essas pessoas ${ }^{31}$. Nessa linha, é possível observar um certo aprimoramento da proteção à medida que se avançou nos ciclos constitucionais.

Diante disso, percebe-se que foram poucos os processos constituintes no NCLA que abarcaram as pessoas LGBTI, mesmo assim, de forma precária, com escassa previsão de direitos. Em contraste, Brasil e

\footnotetext{
26 AVRITZER, Leonardo. O novo constitucionalismo latino-americano: uma abordagem política. In: AVRITZER, Leonardo et al. O constitucionalismo democrático latino-americano em debate: soberania, separação de poderes e sistema de direitos. Belo Horizonte: Autêntica, 2017. p. 19-42.

27 STRECK, Lenio Luiz; OLIVEIRA, Fábio Corrêa Souza de. Reflexões sobre o novo constitucionalismo latino-americano. In: SANTOS, Gustavo Ferreira; STRECK, Lenio Luiz; ARAÚJO, Marcelo Labanca Corrêa de. Direitos e democracia no novo constitucionalismo latino-americano. Belo Horizonte: Arraes Editores, 2016. p. 119-144. p. 119.

28 GARGARELLA, Roberto. Latin american constitutionalism: social rights and the "Engine Room" of the Constitution. Notre Dame Journal of International and Comparative Law, Notre Dame, v. 4, n. 1, p. 8-18, 2014.

29 MAGALHÃES, José Luiz Quadros de. O novo constitucionalismo latino-americano 2: rupturas - diversidade. Revista Eletrônica de Direito do Centro Universitário Newton Paiva, Belo Horizonte, n. 28, p. 10-19, jan./abr. 2016.

30 BELLO, Enzo. O pensamento descolonial e o modelo de cidadania do novo constitucionalismo latino-americano. Revista de Estudos Constitucionais, Hermenêutica e Teoria do Direito (RECHTD), São Leopoldo, v. 7, n. 1, p. 49-61, jan./abr. 2015.

31 LELIS, Rafael Carrano. Em busca das cores latino-americanas: uma análise da proteção constitucional dos direitos LGBTIs na América Latina. Rio de Janeiro: Lumen Juris, 2018.
} 
Colômbia se destacam como os dois países mais avançados na proteção constitucional desses direitos pela via judicial, não obstante a ausência de direitos positivados, diferentemente da Argentina, que obteve avanços por meio de legislação ordinária ${ }^{32}$.

Desse modo, a presente investigação busca compreender quais motivos levaram à não inclusão de direitos LGBTI específicos nas constituições dos países que hoje contam com o maior índice protetivo no nível constitucional, em virtude de importantes decisões do Supremo Tribunal Federal Brasileiro e da Corte Constitucional Colombiana. A proteção pela via do poder judiciário, caracterizada a partir do fenômeno da judicialização de demandas políticas, algo inerente às constituições com pauta alargada de direitos ${ }^{33}$, embora importante, caracteriza-se como precária, tendo em vista a menor segurança jurídica, quando comparado ao texto positivo.

Assim, a identificação dos fatores que levaram à exclusão desses direitos, seja por argumentos contrários ou pela ausência de debates relativos à temática, torna-se essencial para compreender os motivos e o contexto em que se deu a constituinte e a participação das pessoas LGBTI nesse processo. É o que se pretende fazer nas seções seguintes.

\section{Os direitos LGBTI na Assembleia Nacional Constituinte Brasileira de 1987-88}

Embora a Assembleia Nacional Constituinte de 1987-1988 (ANCB) contasse com uma maioria de parlamentares conservadores ou do chamado "centrão", o texto que dela resultou, a Constituição de 1988, mostrou-se, em grande medida, progressista. Isso se deveu a uma série de fatores institucionais e conjunturais, que possibilitaram que setores da esquerda explorassem determinadas previsões regimentais para costurar enunciados mais progressistas e aliados a seus ideais ${ }^{34}$. Contudo, tais estratégias não foram suficientes para que obtivessem êxito na consagração de direitos às pessoas LGBTI, especialmente a vedação à discriminação com base em orientação sexual, principal pleito daqueles que representaram o movimento na Constituinte.

Desse modo, partiu-se à análise dos registros dos anais ${ }^{35} \mathrm{da}$ Constituinte, com a intenção de compreender os argumentos utilizados para impedir a positivação de direitos LGBTI no texto constitucional brasileiro.

Para a seleção dos debates pertinentes a serem analisados, utilizou-se da busca por palavras-chave nas atas das seções. Inicialmente, as palavras definidas para busca foram: orientação sexual; identidade de gênero; sexualidade; sexual; gay; lésbica; travesti; transexual; homossexual; bissexual; homofobia; transfobia; e sexuais. Após o contato inicial com os dados, incluiu-se, dentre os termos de busca, a palavra "homossexualismo", devido à percepção de seu uso frequente pelos parlamentares, não obstante seu caráter pejorativo, já configurado à época. Destaca-se que, embora alguns dos termos escolhidos possam parecer anacrônicos para a época examinada, optou-se pela definição de um leque amplo de termos, ainda que já prevendo a completa ausência de alguns, para que nenhuma discussão relevante fosse perdida.

Desse modo, os termos acima enumerados foram buscados em cada uma das atas de plenário, das comissões e das submissões, na ordem em que foram descritos. A partir do que se encontrou, foram extraídos os

\footnotetext{
32 CORRALES, Javier. Understanding the uneven spread of LGBT rights in Latin America and the Caribbean, 1999-2013. Journal of Research in Gender Studies, New York, v. 7, n. 1, p. 52-82, 2017.

33 BARROSO, Luís Roberto. Judicialização, ativismo judicial e legitimidade democrática. (Syn)Thesis, Rio de Janeiro, v. 5, p. 23-32, 2012.

34 PILATTI, Adriano. A Constituinte de 1987-1988: progressistas, conservadores, ordem econômica e regras do jogo. Rio de Janeiro: Lumen Juris, 2016.

35 Disponíveis em: https://www.senado.leg.br/publicacoes/anais/asp/CT_Abertura.asp. Acesso em: 20 jan. 2019.
} 
debates pertinentes ao tema desta pesquisa, juntamente do seu contexto, tendo as discussões sido separadas de acordo com a comissão ou subcomissão temática à qual pertenciam ou de acordo com as datas das atas, quando se referiam às discussões do plenário. Quando sistematizados em um só documento, os trechos extraídos somaram cerca de setenta páginas que diziam respeito, exclusivamente, a questões afetas à temática LGBTI (principalmente LGB, como será apontado).

Tendo em vista o grande volume de dados encontrados e a necessidade de seu tratamento cuidadoso, optou-se por, nesta etapa da investigação, examinar apenas as discussões travadas nas plenárias, por se entender que elas seriam mais fidedignas a uma visão geral do pensamento dos constituintes, uma vez que as sessões eram compostas, potencialmente, por todos os parlamentares constituintes. Ademais, esperava-se que os argumentos utilizados já tivessem passado por algum nível de reflexão e aprimoramento, uma vez que, conforme previsão regimental, as discussões e elaborações textuais se iniciaram nas subcomissões temáticas, que repassaram seus anteprojetos às comissões, tendo todos sido apreciados também pela Comissão de Sistematização, antes da entrega final do projeto de constituição ao plenário da $\mathrm{ANCB}^{36}$.

Como se sabe, até antes da legislatura que se iniciou em 2019, o Brasil havia tido apenas dois representantes no congresso nacional que se identificavam publicamente como LGBTI, sendo eles Jean Wyllys e Clodovil Hernandes, ambos se identificando como homossexuais cisgêneros, embora apenas o primeiro deles tenha efetivamente lutado por pautas representativas da população LGBTI ${ }^{37}$. Em contrapartida, conclui-se que não participou da ANCB nenhuma pessoa LGBTI, ao menos no que diz respeito à publicização da identidade. Tal fator torna propício que se realize a análise dos dados a partir da perspectiva da antropologia da dominação, proposta por Ochy $\mathrm{Curiel}^{38}$. Trata-se, portanto, de compreender os argumentos e as discussões como travadas entre pessoas não LGBTI, moldando as identidades LGBTI como outros não integrantes do espaço deliberativo. Tal abordagem é essencial para a percepção dos argumentos proferidos, mesmo por aqueles defensores dos direitos dessa população, bem como nas influências que isso pode ter tido no resultado final.

O exame dos anais, de forma geral, indicou que a discussão relativa a direitos LGBTI se restringiu, majoritariamente, à inclusão ou não da vedação à discriminação com base em orientação sexual (ou variações do mesmo termo, como comportamento sexual, opção sexual etc.). Não por coincidência, essa foi a principal aposta feita pelo movimento homossexual institucionalizado no âmbito da Constituinte. Desse modo, o único represente homossexual a falar em nome da causa em audiência pública na $\mathrm{ANCB}^{39}$, João Antônio de Souza Mascarenhas, integrante da organização Triângulo Rosa, apontou essa como a demanda básica objetivada pelo movimento.

Contudo, não se pode deixar de notar que a definição de apenas essa reivindicação essencial não incluiria uma proteção constitucional contra discriminação a pessoas travestis, transexuais e transgêneros ${ }^{40}$. Ocorre,

36 PILATTI, Adriano. A Constituinte de 1987-1988: progressistas, conservadores, ordem econômica e regras do jogo. Rio de Janeiro: Lumen Juris, 2016.

37 CORRALES, Javier. LGBT rights and representation in Latin America and the Caribbean: the influence of structure, movements, institutions, and culture. University of North Carolina: LGBT Representation and Rights Initiative, 2015.

38 CURIEL, Ochy. La nación heterosexual: análisis del discurso jurídico y el régimen heterosexual desde la antropología de la dominación. Bogotá: Impresol Ediciones, 2013.

39 João Mascarenhas participou de audiências em duas subcomissões diferentes, sendo elas: a Subcomissão dos Direitos e Garantias Individuais; e a Subcomissão dos Negros, Populações Indígenas, Pessoas Deficientes e Minorias.

40 Ainda que não se utilizassem, necessariamente, os mesmos termos, já se observava, à época, a diferenciação entre pessoas trans (especialmente as travestis) e homossexuais. Nesse sentido, destaca-se a seguinte passagem, marcada pela transfobia, do discurso do representante do Triângulo Rosa em uma das subcomissões da Constituinte: "É comum fazerem uma falsa identificação entre o homossexual e o travestiprostituto. O Jornal do Brasil, que é um dos jornais mais respeitados do País, põe assim: 'Operação pudor: polícia prende prostitutas e travestis'. Em seguida, vem no corpo da notícia onde os travestis já não são mais travestis. Primeiro eles não eram travestis, eram travestisprostitutos. Realmente, a qualificação deles não era importante. No caso, era a prostituição, não o fato deles se vestirem de mulher. Prostitutas, continuam no corpo da notícia, como prostitutas. E os travestis-prostitutos passam a ser, pura e simplesmente, os homossexuais. O leitor desavisado lê aquilo e termina pensando que homossexual é travesti-prostituto. O que é uma coisa horrorosa". Em: BRASIL. Anais da Assembleia Nacional Constituinte. Atas da Subcomissão dos Negros, Populações 
porém, que, como aponta a historiografia especializada, ainda ao final dos anos oitenta, o movimento hoje caracterizado como LGBTI possuía uma conformação com escassa diversidade, compondo-se, majoritariamente, de pessoas homossexuais cisgêneras e, em geral, focalizando nas demandas de liberação sexual privilegiadas por homens gays brancos. Desse modo, a representação trans no próprio movimento organizado que obtinha visibilidade era extremamente baixa, devido, entre outros, a fatores endógenos excludentes das próprias organizações ${ }^{41}$. Nesse sentido, as principais demandas (em nível organizacional-institucional) da década foram traçadas e encabeçadas por dois grupos de predominância homossexual, o Triângulo Rosa e o Grupo Gay da Bahia, sendo elas: a campanha pela retirada da homossexualidade do Código de Classificação de Doenças do Instituto Nacional de Assistência Médica e Previdência Social (INAMPS), que foi alcançada em 1985; e a inclusão da proibição de discriminação por orientação sexual no novo texto constitucional, demanda que não obteve êxito ${ }^{42}$.

Sendo assim, após a análise de todos os trechos selecionados referentes às atas de plenário, os argumentos encontrados foram segmentados em duas seções: argumentos positivos (ou favoráveis), com relação ao pleito de inclusão de orientação sexual; e argumentos negativos (ou contrários), com relação às demandas específicas do movimento veiculadas à época. Posteriormente, cada uma das segmentações foi qualificada a partir da categorização indutiva dos diferentes tipos de argumentos encontrados. Daqueles argumentos classificados como positivos derivaram duas categorias, conforme disposição na Tabela 01 (que inclui exemplos para as categorias de argumentos estabelecidas), qualificadas como defesa geral e defesa específica.

Tabela 01 - Tipos de Argumentos Positivos

\begin{tabular}{|c|c|}
\hline Categoria & Exemplo \\
\hline Defesa Geral & $\begin{array}{l}\text { "O SR. NILSON GIBSON (PMDB - PE Pro- } \\
\text { nuncia o seguinte discurso.): - Sr. Presidente, Sras } \\
\text { e Srs. Constituintes, presto, inicialmente, minhas } \\
\text { homenagens às mulheres Constituintes eleitas } \\
\text { para redigirem a nova Carta política a ser aprovada } \\
\text { pela Assembléia Nacional Constituinte [...]. Toda- } \\
\text { via, deixando de lado os acontecimentos históricos } \\
\text { da luta pela libertação da mulher, registro que as } \\
\text { conhecidas minorias brasileiras nunca estive- } \\
\text { ram tão ativas politicamente. Mulheres (tratadas } \\
\text { como minoria, do ponto de vista político), negros, } \\
\text { índios, paraplégicos, homossexuais, idosos, gru- } \\
\text { pos ecológicos e esotéricos das mais diferentes } \\
\text { linhas estão mobilizados suprapartidariamente } \\
\text { para trazer suas contribuições à Constituinte. Em } \\
\text { comum, esses setores trarão à Assembléia Na- } \\
\text { cional Constituinte sugestões pela [sic] quais lu- } \\
\text { tarão: o fim das classificações discriminatórias } \\
\text { e o princípio da igualdade entre todos os brasi- } \\
\text { leiros. [...] os homossexuais, [pedem] liberdade de } \\
\text { opção sexual"1 (grifo nosso). }\end{array}$ \\
\hline
\end{tabular}

Indígenas, Pessoas Deficientes e Minorias. Ata da $8^{a}$ Reunião Ordinária Realizada em 29 de abril de 1987. p. 101. Disponível em: http://www.senado.leg.br/publicacoes/anais/constituinte/7c_Subcomissao_Dos_Negros,_Populacoes_Indigenas,.pdf.

41 FACCHINI, Regina. Sopa de letrinhas? Movimento homossexual e produção de identidades coletivas nos anos 1990. Rio de Janeiro: Garamond, 2005.

${ }^{42}$ SIMÕES, Júlio Assis; FACCHINI, Regina. Na trilha do arco-íris: do movimento homossexual ao LGBT. São Paulo: Editora Fundação Perseu Abramo, 2009. 
Conforme observado, trata-se de uma menção que não tem por intuito, propriamente, argumentar em favor da manutenção ou inclusão de direitos LGBTI. Desse modo, ainda que uma lembrança importante, não colabora, de forma direta, para a concretização da previsão constitucional. Tendo sido a aparição mais recorrente nas atas de plenário, identifica-se que a pauta talvez não tenha sido elencada como prioridade, nem mesmo entre os progressistas. Como será visto, apenas uma vez se levantou um argumento de defesa específica $^{45}$.

A respeito dessa questão, destaca-se a importância do fator da representação, não somente enquanto elemento de garantia de uma legitimidade real do processo constituinte, conforme apontado por Ochy Curiel $^{46}$, mas, essencialmente, enquanto dimensão de efetivação de justiça. É nesse sentido que Nancy Fraser ressalta que a representação, em sua faceta político-comum, é imprescindível para a adequada veiculação de demandas por redistribuição e reconhecimento, integrando uma dimensão autônoma da própria justiça ${ }^{47}$.

Por outro lado, os argumentos de defesa específica foram utilizados para classificar aquelas intervenções voltadas exclusivamente ao reconhecimento de direitos LGBTI. No caso em questão, à defesa da inclusão do termo orientação sexual no rol de discriminações vedadas constitucionalmente. Conforme anteriormente ressaltado, sua aparição nas atas de plenário se deu apenas uma vez, a partir de fala do constituinte José Genoíno (PT-SP) em defesa de sua proposta de Emenda Aditiva n ${ }^{\circ} 1225$, que objetivava a inclusão do termo orientação sexual no artigo terceiro da Constituição ${ }^{48}$. É de sua fala que se retirou o exemplo elencado na Tabela 01. Na ocasião, o proponente realizou engenhosa argumentação, tentando traçar, entre outros argumentos, uma correlação entre o termo e uma proteção a figuras religiosas, muito provavelmente buscando dissuadir aqueles constituintes que frequentemente se apegavam a argumentos também religiosos para negar a possibilidade de inserção do termo no texto constitucional. É o trecho que se destaca:

O que nós estamos colocando aqui é que aquelas pessoas que façam diferentes opções sexuais, movidas por uma determinada orientação, não sofram discriminação. O padre e a freira, por exemplo, recebem uma determinada orientação sexual. Isto é uma orientação sexual. Eles não podem ser discriminados. $\mathbf{O}$ celibatário faz uma opção sexual, recebe uma orientação sexual, portanto, não pode ser discriminado ${ }^{49}$. (Grifo nosso).

Não é possível inferir se o constituinte seguiu tal linha de argumentação consciente dos equívocos da correlação traçada (efetivamente atuando de forma estratégica) ou se realmente entendia como pertinente a comparação. O certo é que, mesmo na defesa da positivação do referido direito, cometeram-se diversos equívocos, como no trecho destacado, com relação aos significados, vivências e expectativas das próprias pessoas LGBTI. Trata-se, certamente, de uma das consequências da ausência de representação LGBTI na constituinte, não somente de uma representação descritiva (por presença), mas também substantiva (por agenda) de forma devidamente informada. Em seguida, o parlamentar continuou sua defesa evidenciando as formas de discriminação contra homossexuais no Brasil à época, o que justificaria a necessidade de positivação dessa proteção específica. Entretanto, não obstante seus esforços, a emenda aditiva foi rejeitada com 317 votos contrários, 130 favoráveis e 14 abstenções ${ }^{50}$.

23 de junho de 1987. p. 517-518. Disponível em: http://www.senado.leg.br/publicacoes/anais/constituinte/N005.pdf.

45 Tal análise se refere apenas à participação em plenário, uma vez que houve importantes defesas específicas nas comissões e subcomissões realizadas por diferentes constituintes, em especial José Genoíno (PT-SP), Benedita da Silva (PT-RJ) e José Paulo Bisol (PMDB-RS).

46 CURIEL, Ochy. La nación heterosexual: análisis del discurso jurídico y el régimen heterosexual desde la antropología de la dominación. Bogotá: Impresol Ediciones, 2013.

47 FRASER, Nancy. Reenquadrando a justiça em um mundo globalizado. Lua Nova, São Paulo, v. 77, p. 11-39, 2009.

48 BRASIL. Anais da Assembleia Nacional Constituinte. Atas de Plenário. Ata da 189 $9^{a}$ Sessão da Assembleia Nacional Constituinte, em 28 de janeiro de 1988. p. 422. Disponível em: http://www.senado.leg.br/publicacoes/anais/constituinte/N011.pdf.

49 BRASIL. Anais da Assembleia Nacional Constituinte. Atas de Plenário. Ata da $189^{\text {a }}$ Sessão da Assembleia Nacional Constituinte, em 28 de janeiro de 1988. p. 422. Disponível em: http://www.senado.leg.br/publicacoes/anais/constituinte/N011.pdf.

50 BRASIL. Anais da Assembleia Nacional Constituinte. Atas de Plenário. Ata da $189^{a}$ Sessão da Assembleia Nacional Constituinte, em 28 de janeiro de 1988. p. 423. Disponível em: http://www.senado.leg.br/publicacoes/anais/constituinte/N011.pdf. 
Passada a breve análise dos argumentos positivos, segue-se ao exame dos posicionamentos negativos, que se mostraram mais numerosos e variados no plenário. Assim, a Tabela 02 evidencia as categorias estabelecidas para as diferentes justificações apontadas pelos parlamentares em sua recusa à previsão de direitos LGBTI.

Tabela 02 - Tipos de Argumentos Negativos

\begin{tabular}{|c|c|}
\hline Categoria & Exemplo \\
\hline Base Religiosa & $\begin{array}{l}\text { "ELIEL RODRIGUES (PMDB - PA. Pronuncia } \\
\text { o seguinte discurso.): [...] Como Engenheiro Civil } \\
\text { e membro da Igreja Evangélica "Assembléia } \\
\text { de Deus" [...] Estamos empenhados em trabalhar } \\
\text { num espírito de solidariedade cristã, unido aos } \\
\text { demais de mesmo ideal, na busca dos altos interes- } \\
\text { ses e necessidades do Povo brasileiro. Dentro dos } \\
\text { princípios contidos nas Sagradas Escrituras, } \\
\text { propomo-nos apresentar diretrizes que promovam } \\
\text { o bem-estar social, político, moral e espiritual da na- } \\
\text { cionalidade brasileira, norteados pelos parâmetros } \\
\text { da justiça, do juízo e da eqüidade [...] Pretendemos } \\
\text { uma legislação em que a paternidade e a maternida- } \\
\text { de se tornem algo de responsabilidade, tanto peran- } \\
\text { te Deus como ante a sociedade, contribuindo para } \\
\text { reduzir o problema do menor abandonado e da de- } \\
\text { linqüência juvenil. Daí a nossa preocupação de } \\
\text { que se devem tomar medidas contrárias a atual } \\
\text { prática do amor livre e do homossexualismo, } \\
\text { pelos visíveis prejuízos que causam a toda a so- } \\
\text { ciedade, como é o caso da recente epidemia da } \\
\text { AIDS. [...] feliz é a nação cujo Deus é o Senhor". } \\
\text { (grifo nosso) }\end{array}$ \\
\hline Repugnância & $\begin{array}{l}\text { “O SR. CONSTITUINTE VALMIR CAMPELO } \\
\text { (PFL - DF. Pronuncia o seguinte discurso.): [...] Sr. } \\
\text { Presidente, entre tantos assuntos a serem tratados } \\
\text { na lei maior, todos de grande importância para a } \\
\text { organização política do País, acredito que devemos } \\
\text { focalizar com especial carinho o título que trata da } \\
\text { Ordem Social e, dentro dele, o capítulo referente à } \\
\text { família, ela que é célula básica da sociedade. [...] } \\
\text { Nesse vagar pelas ruas e pelas praças misturam-se } \\
\text { ao que há de pior na sociedade, a começar pe- } \\
\text { los homossexuais e prostitutas, habituais freqüen- } \\
\text { tadores da noite."4 (Grifo nosso) }\end{array}$ \\
\hline
\end{tabular}




\begin{tabular}{|c|c|}
\hline Categoria & Exemplo \\
\hline Consequencialismo Falacioso & $\begin{array}{l}\text { "O SR. SALATIEL CARVALHO (PFL - PE. Pro- } \\
\text { nuncia o seguinte discurso.): [...]A inclusão da ex- } \\
\text { pressão "Orientação Sexual" na alínea "f" inciso } \\
\text { III, art. 12, passa a estabelecer a garantia consti- } \\
\text { tucional aos portadores e praticantes de qual- } \\
\text { quer impulso, tendência ou inclinação sexual. } \\
\text { Permitir que tal expressão seja mantida no texto do } \\
\text { Projeto é, no mínimo, contribuir para uma Constitu- } \\
\text { ição contraditória, já que consideramos fundamen- } \\
\text { tal e básico a nova Carta Constitucional ser precisa } \\
\text { e clara nos dispositivos que defenderão a moral, os } \\
\text { bons costumes e a família. Que tipo de impulso, } \\
\text { tendência ou inclinação sexual visa garantir o } \\
\text { referido Projeto? A contradição a que nos referi- } \\
\text { mos vai resultar na cobertura legal que terão os } \\
\text { portadores de desvios ou taras sexuais, os quais } \\
\text { terão um preceito constitucional que poderá ser in- } \\
\text { vocado para justificar comportamentos sexuais } \\
\text { anormais, porém definidos como inclinação } \\
\text { ou tendência sexual. Sem dúvida, esta situação } \\
\text { vai gerar confronto com as leis destinadas a punir } \\
\text { a prática de aberrações e desvios, que poderão, in- } \\
\text { clusive, gerar a violência sexual e os conseqüen- } \\
\text { tes malefícios. É sabido que a inclusão do termo } \\
\text { "Orientação Sexual” atende à solicitação dos } \\
\text { grupos homossexuais. Se o parágrafo pretende } \\
\text { garantir constitucionalmente o homossexua- } \\
\text { lismo, já é falho por garantir uma anormali- } \\
\text { dade sexual, que, mesmo sendo uma realidade, } \\
\text { não deve receber garantia constitucional explícita. } \\
\text { Como pessoa humana os homossexuais serão } \\
\text { contemplados com o princípio constitucional } \\
\text { da igualdade perante a lei. Somos, portanto, pela } \\
\text { supressão do termo “Orientação Sexual”, o que } \\
\text { evitará ambigüidades na interpretação da nova lei, } \\
\text { que aspiramos seja também concisa e definitiva. Era } \\
\text { o que tinha a dizer, Sr. Presidente." (grifo nosso) }\end{array}$ \\
\hline \multicolumn{2}{|c|}{$\begin{array}{l}3 \text { BRASIL. Anais da Assembleia Nacional Constituinte. Atas de Plenário. Ata da } 23^{2} \text { Sessão da Assembleia Nacional Constituinte, } \\
\text { em } 24 \text { de fevereiro de 1987. p. 529. Disponível em: http://www.senado.leg.br/publicacoes/anais/constituinte/N001.pdf. } \\
4 \text { BRASIL. Anais da Assembleia Nacional Constituinte. Atas de Plenário. Ata da } 76^{a} \text { Sessão da Assembleia Nacional Constituinte, } \\
\text { em } 03 \text { de junho de 1987. p. 81. Disponível em: http://www.senado.leg.br/publicacoes/anais/constituinte/N005.pdf. } \\
5 \text { BRASIL. Anais da Assembleia Nacional Constituinte. Atas de Plenário. Ata da } 141^{a} \text { Sessão da Assembleia Nacional Constituinte, } \\
\text { em } 18 \text { de agosto de 1987. p. 96-97. Disponível em: http://www.senado.leg.br/publicacoes/anais/constituinte/N008.pdf. }\end{array}$} \\
\hline
\end{tabular}

Como se observa, a maior frequência das manifestações negativas ocasionou, também, sua diferenciação em mais classificações, dessa vez sendo qualificadas em três diferentes categorias: base religiosa, repugnância e consequencialismo falacioso.

O primeiro deles, também o mais frequente, engloba as declarações que se embasaram em elementos 
de matriz religiosa (dogmas, textos bíblicos etc.) para negar a proteção constitucional a homossexuais por meio da condenação de suas práticas sexuais. Todas as manifestações desse tipo foram realizadas com base, exclusivamente, em crenças cristãs. Algo irônico, quando se considera que foi a mesma Assembleia Constituinte que consagrou a laicidade estatal por meio do reconhecimento da liberdade de crença e exercício de cultos religiosos, consoante art. $5^{\circ}$, VI, da atual Constituição brasileira. Além disso, observou-se que os grupos religiosos foram aqueles mais empenhados (e articulados) na retirada do termo orientação sexual do texto final e seus argumentos enfocavam sua moral religiosa sob perspectiva universal, como se devesse ser aplicada a todos, como nos exemplos abaixo:

ELIEL RODRIGUES (PMDB - PA. Pronuncia o seguinte discurso.): Sr. Presidente, Srs. Constituintes. Ceio [sic], sinceramente, que estamos todos empenhados na solução dos diversos problemas que se abatem sobre a nossa querida Pátria. Urn [sic] deles, bem recente é relativo à AIDS (Síndrome da Imunodeficiência Adquirida), doença ainda sem cura, que já registrou mais de 1.300 casos no Brasil, a partir de 1982. [...] Assim sendo, é dos mais louváveis e oportuno o propósito do Ministério da Saúde, em combater esse flagelo, numa luta sem fronteiras, ao qual todos devemos unir-nos. Achamos, contudo, que, como cristãos devemos ter uma palavra que aborde mais profundamente o assunto, buscando seu fundamento e raízes, para erradicá-lo. Com isso estaremos contribuindo em benefício da população brasileira, trazendo-lhe ao conhecimento que a origem dessa enfermidade resulta de um inteiro desvirtuamento dos princípios naturais e salutares, estabelecidos por Deus, para o relacionamento sexual da raça humana. Tão sério é esse desvio do comportamento normal humano, em suas origens, que Deus, já nos primórdios da História, teve de intervir, destruindo, entre outras, as cidades de Sodoma e Gomorra, por suas extremadas devassidões. É, portanto, com sobeja razão que, divinamente inspirado, o apóstolo São Paulo, escrevendo sua epístola aos cristãos romanos, assim se expressa: [...] 'E, semelhantemente, também os varões, deixando o uso natural da mulher, se inflamaram sua sensualidade uns para com os outros, varão com varão, comentendo [sic] torpeza e recebendo em si mesmos a recompensa que convinha ao seu erro [...] Os quais, conhecendo a justiça de Deus (que são dignos de morte os que tal coisa praticam), não somente as fazem, mas também consentem aos que as fazem.' [...] É meu intuito, portanto, ao ocupar novamente a tribuna desta assembléia, conclamar os ilustres constituintes para que, ao elaborarmos nossa Carta Magna, busquemos dotá-la de princípios morais, não tolerando a prática do homossexualismo e do sexo livre, pelos males que trazem em seu bojo, entre eles a terrível AIDS. Creio que; neste pronunciamento, Sr. Presidente, estamos representando o sentimento e a consciência de milhões de cristãos brasileiros, [...] apesar de sua etiologia biológica, essa doença degenerativa tem conotação maligna. Infelizmente se caracteriza ela como um mal necessário, um mal de reparação moral, um castigo da própria natureza vilipendiada, pois tudo que alguém semear também colherá. ${ }^{51}$ (Grifo nosso)

O SR. JOÃO DE DEUS ANTUNES (PDT RS. Sem revisão do orador.): - Sr. Presidente, Srs. Constituintes: Assomamos a esta tribuna para manifestar a nossa alegria pelo fato desta Assembléia Nacional Constituinte contar, desde ontem, com um exemplar da Bíblia Sagrada. [...] Quando a imoralidade assume papel de destaque no seio da nossa sociedade, quando grupos satânicos e perversos disseminam veneno sobre nossos jovens, através do nudismo, homossexualismo, revistas pornográficas, Je Vous Salue Marie, Teledeum, e tantas outras perversidades que pervertem o sentido humano, nós damos Graças a Deus por vermos os cristãos unidos na sua fé, ainda que existam diferenças nos nossos pontos de vista, políticos ideológicos, estamos convictos de que, na palavra de Deus, o homem encontra a bússola que norteia seus verdadeiros ideais na direção do Espírito Santo de Deus. $^{52}$ (Grifo nosso)

O SR. SALATIEL CARVALHO (PFL - PE. Pronuncia o seguinte discurso.): [...] Outra questão polêmica enfrentamos na Comissão da Ordem Social, que tratou das minorias e onde os homossexuais reivindicaram a legalização dos seus movimentos e direitos na futura Constituição. Esta é uma batalha que ainda não terminou. Apesar do nosso veemente protesto, também registrado pela imprensa, os membros da Comissão votaram favoravelmente aos interesses dos homossexuais, ficando no

51 BRASIL. Anais da Assembleia Nacional Constituinte. Atas de Plenário. Ata da 29a Sessão da Assembleia Nacional Constituinte, em 09 de março de 1987. p. 07-08. Disponível em: http://www.senado.leg.br/publicacoes/anais/constituinte/N002.pdf.

52 BRASIL. Anais da Assembleia Nacional Constituinte. Atas de Plenário. Ata da $40^{a}$ Sessão da Assembleia Nacional Constituinte, em 26 de março de 1987. p. 326. Disponível em: http://www.senado.leg.br/publicacoes/anais/constituinte/N002.pdf. 
texto do anteprojeto a garantia constitucional para o exercício de qualquer comportamento sexual. [...] Mais do que nunca vamos precisar das orações dos evangélicos de todo o Brasil. [...] A nossa estratégia é agregar à bancada evangélica outros Constituintes não evangélicos e formarmos um bloco para votarmos unido [sic] em defesa das questões de maior relevância para que possamos garantir uma Constituição limpa e justa, baseada nos princípios cristãos e que possa honrar a Nação brasileira, bem como garantir ampla liberdade para que o Evangelho continue sendo pregado com todo o vigor. ${ }^{53}$ (Grifo nosso)

O encontrado reforça o fato de as religiões de matriz cristã serem historicamente conservadoras com relação a questões de diversidade sexual e de gênero, caracterizadas por diversos casos de intolerância com relação a pessoas LGBTI. Essa realidade permanece se manifestando de forma institucionalizada, ainda no Brasil de hoje, no qual a chamada "Frente Parlamentar Evangélica" continua atuando de forma conjunta e contrária a quaisquer projetos voltados à proteção de indivíduos LGBTI ${ }^{54}$.

Avançando na análise, a segunda categoria de justificações foi nomeada com inspiração naquilo que Martha Nussbaum caracteriza como politics of disgust (política da repugnância), a partir da qual descreve prática de completa aversão e repulsa a comportamentos e pessoas homossexuais. Segundo a autora, trata-se de uma forma de negação da humanidade completa desses indivíduos ${ }^{55}$. Nesse sentido, embora também a maioria das argumentações de base religiosa apontassem para uma repugnância dos parlamentares com relação aos indivíduos LGBTI, essa categoria abarcou aquelas falas que expressavam sua repulsa de forma autônoma, sem vinculação a posicionamentos religiosos.

Trata-se, nesses casos, de expressão da homofobia em seu modo irracional (afetivo ou psicológico), conforme categorizado pelo argentino Daniel Borrillo. Segundo o autor, tal manifestação se caracteriza pela condenação à homossexualidade, sendo vista como um "sentimento de medo, aversão e repulsa" ${ }^{56}$ por gays e lésbicas, tratando-se de uma "verdadeira manifestação emotiva, do tipo fóbico, comparável à apreensão que pode ser experimentada em espaços fechados (claustrofobia) ou diante de certos animais (zoofobia)" 57 . Essa forma se contrasta com a homofobia cognitiva (ou social), marcada pela tentativa de perpetuação da diferenciação entre homo e heterossexuais, que se materializa na negação de direitos a esses indivíduos, ainda que não possuam aversão pública a eles ${ }^{58}$. Exemplos dessa segunda forma, mais sofisticada, não apareceram de forma explícita nas discussões de plenário (embora a negação de direitos esteja, obviamente, sempre vinculada aos casos de repugnância), mas foram frequentes, sobretudo, nos debates das comissões e subcomissões. Nesse sentido, repetiram-se falas de constituintes que indicavam não possuir preconceitos contra homossexuais, mas que acreditam ser um exagero a previsão constitucional de direitos.

Ainda nessa categoria de argumentos, foram reiteradas expressões, também, de transfobia pelos parlamentares constituintes. Nesse sentido, destacam-se duas falas, abordando o mesmo fato:

O SR. FRANCISCO ROLLEMBERG: [...] Ontem nos foi apresentado um grupo de homossexuais masculinos, envelhecidos, encanecidos, a injetarem-se para criar seios, ampliar nádegas, tornar braços roliços, rostos mais arredondados, para praticarem o homossexualismo como profissão [...] Precisamos encontrar uma maneira de orientar os nossos filhos, orientar os nossos jovens, orientar esta geração que está nascendo, está crescendo e vai gerir, conduzir os destinos do Brasil de amanhã. Isto só poderemos fazer se mantivermos a libertinagem afastada da liberdade e da democracia, e cuidarmos de dar aos nossos meninos a educação necessária, básica, moral, religiosa e a orientação sexual, no seu momento

\footnotetext{
53 BRASIL. Anais da Assembleia Nacional Constituinte. Atas de Plenário. Ata da 101ª Sessão da Assembleia Nacional Constituinte, em 15 de julho de 1987. p. 301-02. Disponível em: http://www.senado.leg.br/publicacoes/anais/constituinte/N006.pdf.

54 VITAL, Christina; LOPES, Paulo Victor Leite. Religião e política: uma análise da atuação dos parlamentares evangélicos sobre direitos das mulheres e de LGBTs no Brasil. Rio de Janeiro: Fundação Heinrich Böll, 2012.

55 NUSSBAUM, Martha C. From disgust to humanity: sexual orientation and constitutional law. New York: Oxford University Press, 2010.

56 BORRILLO, Daniel. Homofobia: história e crítica de um preconceito. Belo Horizonte: Autêntica Editora, 2016. p. 24.

57 BORRILLO, Daniel. Homofobia: história e crítica de um preconceito. Belo Horizonte: Autêntica Editora, 2016. p. 24.

58 BORRILLO, Daniel. Homofobia: história e crítica de um preconceito. Belo Horizonte: Autêntica Editora, 2016.
} 
oportuno. ${ }^{59}$ (Grifo nosso)

O SR. JESUS TAJRA: [...] Ontem, chegava eu de São Paulo à meia-noite, sem sono, e liguei a televisão, que estava no canal correspondente à TVS. A cena era a que o Constituinte Nelson Aguiar se referia, com uma particularidade grotesca. Lá estavam os homossexuais a ensinar como colocar silicone no corpo, um deles, inclusive, fazendo a demonstração. Com uma seringa e uma agulha perfurava o bico do peito de um deles que se chamavam, entre si, de ela. Era tão chocante, tão repugnante, que imediatamente mudei o canal, pois tornou-se insuportável aquela cena grotesca. ${ }^{60}$ (Grifo nosso)

Embora não se possa definir uma identidade (seja como travesti, seja como transexual) às pessoas descritas pelos parlamentares, uma vez que a identidade, nesses casos, pressupõe a autoidentificação do indivíduo, pode se afirmar que se trata de expressões de gênero não-binárias e não-cisgêneras. Desse modo, seu enquadramento enquanto homossexuais invisibiliza vivências que são mais específicas e sofrem outros tipos de opressão, somando-se à "extensa série de percepções estereotipadas negativas e de atos discriminatórios contra homens e mulheres transexuais e travestis" e de expressão de medo ou ódio com relação às pessoas trans, que caracterizam, em conjunto, práticas transfóbicas ${ }^{61}$.

Os exames desses argumentos nos levam, mais uma vez, à importância da representação. Não obstante sejam sempre essenciais, conforme já apontando, os exercícios de representação, tanto descritiva quanto substantiva, nesse caso, parece importante ressaltar um efeito ocasionado, sobretudo, pela representação descritiva. Trata-se, tal modalidade, daquela representação exercida por pessoas que sejam efetivamente LGBTI, podendo ser caracterizada, também, como representação passiva, simbólica ou por presença. Conforme aponta Andrew Reynolds, em ampla investigação empírica realizada sobre o tema, a maior presença de legisladores LGBTI publicamente assumidos nos parlamentos tem relação direta com o avanço na aprovação de propostas legislativas voltadas a essa população. $\mathrm{O}$ autor ressalta que a presença de pessoas gays, lésbicas, bissexuais ou trans, nas casas legislativas, possui um efeito transformativo nas ações, visões e votos de parlamentares heterossexuais e cisgêneros. Isso porque a convivência com indivíduos LGBTI aumenta sua empatia com relação ao grupo, pois torna mais próximas suas realidades, que deixam de ser vivências de "outros abstratos". É o que o autor identificou como "familiaridade por presença"

Nesse sentido, ainda que não seja garantia, a presença de constituinte LGBTI poderia ter colaborado para a mudança de visão dos parlamentares e talvez evitado a grande frequência de argumentos de repugnância, senão contribuído para a aprovação da inclusão do termo orientação sexual no texto constitucional.

Adiante, o último tipo de argumento negativo encontrado foi caracterizado como consequencialista falacioso. Essa categoria representa discursos proferidos por parlamentares que tentavam, de forma alarmista, indicar falsas decorrências da constitucionalização da vedação à discriminação com base em orientação sexual. Nesse sentido, os parlamentares alegaram que tal positivação levaria à legalização de "perversões sexuais" no Brasil, abrindo espaços para diversas práticas, como pedofilia e abusos sexuais, em virtude da suposta indefinição do termo "orientação sexual". Tal atitude se assemelha ao uso que Jeffrey Weeks deu à ideia "pânico moral" enquanto mecanismo utilizado para delineação das políticas sexuais ("shaping of sexual politics") ${ }^{63}$, o qual Gayle Rubin interpretou como caracterizando o "momento político do sexo, durante o qual atitudes

\footnotetext{
59 BRASIL. Anais da Assembleia Nacional Constituinte. Atas de Plenário. Ata da $119^{a}$ Sessão da Assembleia Nacional Constituinte, em 02 de agosto de 1987. p. 27. Disponível em: http://www.senado.leg.br/publicacoes/anais/constituinte/N007.pdf.

60 BRASIL. Anais da Assembleia Nacional Constituinte. Atas de Plenário. Ata da $119^{\mathrm{a}}$ Sessão da Assembleia Nacional Constituinte, em 02 de agosto de 1987. p. 30. Disponível em: http://www.senado.leg.br/publicacoes/anais/constituinte/N007.pdf.

${ }^{61}$ JESUS, Jaqueline Gomes de. Transfobia e crimes de ódio: assassinatos de pessoas transgênero como genocídio. In: MARANHÃO, F.; ALBUQUERQUE, Eduardo Meinberg de (orgs.). (In)visibilidade trans 2: história agora, v. 16, n. 2, p. 101-123, 2013. p. 106.

62 REYNOLDS, Andrew. Representation and rights: the impact of LGBT legislators in comparative perspective. American Political Science Review, Cambridge, v. 107, n. 02, p. 259-274, 2013.

63 WEEKS, Jeffrey. Sex, politics and society: the regulation of sexuality since 1800. London: New York: Routledge, 2012. p. 19.
} 
difusas são canalizadas na forma de ação política e, a partir disso, de transformação social" ${ }^{64}$. Assim, ainda que o conceito de pânico moral procure englobar situações sociais mais amplas, as atitudes dos parlamentares constituintes, em sua cruzada contra os direitos homossexuais, podem ser compreendidas sob o prisma de uma expressão localizada de pânico moral, atuando diretamente sobre as dissidências sexuais, a partir da recriminação de seus comportamentos. Nesse sentido, destaca Rubin que "mesmo quando se reconhece que uma atividade é inofensiva, ela pode ser proibida com base na alegação de que 'leva' a algo muito pior" ${ }^{5}$. É o que embasa a lógica desse último grupo de argumentos.

Por fim, dentre as falas proferidas na plenária da Assembleia Constituinte Brasileira, ainda merece destaque uma declaração realizada por um dos constituintes do PFL:

O SR. MÁRIO ASSAD (PFL - MG. Pronuncia o seguinte discurso.): [...] desse povo pelo qual já passou em julgado os textos do anteprojeto escrito sob o seu atento acompanhamento, avalizado por fidedignos represente [sic] dos trabalhadores e dos empresários, dos profissionais liberais e dos funcionários civis e militares; dos professores de escolas públicas e privadas; dos bancários e banqueiros; dos comerciários e dos comerciantes; dos operários e dos industriais; das mulheres, dos negros, dos homossexuais. ${ }^{66}$ (Grifo nosso).

Como se vê, o constituinte pretende fazer crer que, a partir da mera participação em audiência pública de apenas $u m$ ativista gay, em somente duas subcomissões, o texto constitucional (que nem mesmo incluiu aquilo pelo qual tal ativista advogou em sua intervenção) estaria aprovado e legitimado pelos "homossexuais". Mais uma vez, vê-se, de forma latente, a necessidade, para manutenção de hegemonia, de legitimação do pacto social pelos grupos não hegemônicos e não representados. Isso porque a manutenção dessa hegemonia se constrói, justamente, a partir da submissão, exploração e falsa inclusão dos conjuntos oprimidos. Tenta-se, assim, caracterizar o texto constitucional resultado do pacto hegemônico, heterossexual e cisgênero, enquanto representante de toda nação, falsamente indicando que as pessoas LGBTI estariam abarcadas nesse ideal de nação.

\section{Os direitos LGBTI na Assembleia Nacional Constituinte Colombiana de 1991}

Em julho de 1991, foi promulgada a Constituição Política da Colômbia, fruto do trabalho da Assembleia Nacional Constituinte Colombiana (ANCC), em substituição à Constituição de 1886. A convocação da ANCC decorreu de pressão popular, em especial por parte do movimento estudantil que incentivou a população a depositar a "sétima cédula", como meio de se manifestar favoravelmente à convocatória da ANCC, nas urnas referentes às eleições municipais de março de 1990. Em virtude dessa iniciativa, por meio do decreto legislativo n $^{\circ} 927$ de 3 de março de 1990, o presidente Virgilio Barco determinou que, no dia das eleições presidenciais de 1990, também fosse votada a possibilidade de instalação da ANCC ${ }^{67}$. Ressalta-se que o referido decreto foi declarado constitucional pela Corte Suprema de Justiça em 24 de maio de 1990, e as eleições ocorreram três dias depois. Apurado o resultado, verificou-se que 5.236 .863 de votos, o que equivale a $88 \%$ do total, foram favoráveis à convocatória da $\mathrm{ANCC}^{68}$.

As eleições para a ANCC foram realizadas em dezembro de 1990, sendo registrada a participação de

\footnotetext{
64 RUBIN, Gayle. Políticas do sexo. São Paulo: Ubu Editora, 2017. p. 109.

65 RUBIN, Gayle. Politicas do sexo. São Paulo: Ubu Editora, 2017. p. 110.

66 BRASIL. Anais da Assembleia Nacional Constituinte. Atas de Plenário. Ata da $98^{a}$ Sessão da Assembleia Nacional Constituinte, em 09 de julho de 1987. p. 169-70. Disponível em: http://www.senado.leg.br/publicacoes/anais/constituinte/N006.pdf.

67 CAMARGO, Sergio Roberto Matias. La Asamblea Nacional Constituyente de 1991 y el nuevo constitucionalismo latinoamericano. Dialógos des saberes, Bogotá, n. 44, p. 29-44, ene./jun. 2016.

68 GUEVARA, Andrés Dávila Ladrón de. Democracia pactada: el Frente Nacional y el proceso constituyente de 1991 en Colombia. Lima: Institut Français D'études Andines, 2002.
} 
3.710.557 eleitores, o que representa, apenas, $27,1 \%$ do potencial eleitoral ${ }^{69}$. Foram eleitos 70 constituintes, e, em razão de acordos de paz posteriores ao início da ANCC, quatro ex-guerrilheiros também se tornaram membros da assembleia, apesar de apenas dois deles possuírem direito a voto. Apenas quatro constituintes eram mulheres ${ }^{70}$. Destaca-se que nenhum grupo logrou maioria absoluta na ANCC, visto que, com 25 representantes, o Partido Liberal Colombiano foi o que obteve maior representação, enquanto os indígenas, com 2 representantes, obtiveram o menor número ${ }^{71}$. Todavia, 44 constituintes eram integrantes de partidos políticos convencionais (Liberais e Conservadores), logo, as forças políticas tradicionais foram dominantes na $\mathrm{ANCC}^{72}$.

Foi adotado um modelo descentralizado de condução da ANCC, de modo que havia ausência inicial de projetos, deixando espaço para que, durante as deliberações, fossem apresentadas propostas de diversas iniciativas $^{73}$. A ANCC foi dividida em cinco comissões permanentes temáticas, além de uma codificadora, cuja missão era sistematizar as discussões e as alterações sugeridas ${ }^{74}$.

Inicialmente, foi realizado o levantamento dos debates realizados no âmbito das comissões, porém, para preservar o paralelismo com relação ao Brasil, apenas as discussões da plenária serão objeto de análise. Nesse sentido, faz-se necessário mencionar que suas reuniões ocorreram em diversos momentos durante o ano de 1991: durante o mês de fevereiro, a plenária promoveu a instalação da ANCC, bem como a formulação do seu regulamento; de maio a meados de junho, foi realizada a primeira rodada de debates dos trabalhos desenvolvidos pelas comissões; e, ao final de junho a 4 de julho, data da promulgação da nova Constituição, realizou-se a última rodada de debates. Todas as atas desses períodos serão analisadas, perfazendo um total de 68 documentos, disponíveis no site da Biblioteca Virtual del Banco de la República.

Inicialmente, por meio de mecanismos de pesquisa, verificou-se quais atas apresentavam termos que têm relação direta com a temática do presente trabalho, quais sejam: orientación sexual; identidad de género; sexualidad; sexual; gay; lesbiana; travesti; transexual; homosexual; bisexual; homofobia; transfobia; sexuales; transgénero; homosexualismo. Tais expressões consistem na versão em espanhol daquelas utilizadas na seção referente ao Brasil.

Antes de expor os resultados, é necessário ressalvar que, aparentemente, as atas encontradas são documentos digitalizados, de modo que, nem sempre, havia o reconhecimento de caracteres. Com isso, apesar de as atas conterem algum termo, poderia acontecer de os mecanismos de busca não identificarem a sua presença. Todavia, nas ocasiões em que essa situação aconteceu, a utilização dos termos mais genéricos, como "sexual", "sexuales" e "sexualidad", facilitou a detecção das ocorrências relevantes. A utilização de palavras-chave genéricas também fez com que expressões sem pertinência com a temática do trabalho fossem encontradas, como é o caso de "abuso sexual" e "relaciones sexuales", cuja análise foi descartada. Outra dificuldade encontrada foi a mera reprodução das falas dos constituintes, sem que as atas indicassem quem foi o responsável por elas.

No que tange aos resultados, foram encontradas pouquíssimas ocorrências, apenas nos dias 3, 28 e 29 de junho de 1991.

A primeira se referia à discussão sobre administração da justiça e a necessidade de garantia dos direitos

\footnotetext{
69 GUEVARA, Andrés Dávila Ladrón de. Democracia pactada: el Frente Nacional y el proceso constituyente de 1991 en Colombia. Lima: Institut Français D'études Andines, 2002.

70 CAYCEDO, Claudia Hurtado. La marcha LGBT: para ampliar el canon de la ciudadanía con las diversidades sexuales. 2010. Dissertação (Mestrado em Estudios Culturales) - Facultad de Ciencias Sociales, Pontificia Universidad Javeriana, Bogotá, 2010. p. 24.

71 CURIEL, Ochy. La nación heterosexual: análisis del discurso jurídico y el régimen heterosexual desde la antropología de la dominación. Bogotá: Impresol Ediciones, 2013.

72 CAYCEDO, Claudia Hurtado. La marcha LGBT: para ampliar el canon de la ciudadanía con las diversidades sexuales. 2010. Dissertação (Mestrado em Estudios Culturales) - Facultad de Ciencias Sociales, Pontificia Universidad Javeriana, Bogotá, 2010. p. 22.

73 HENAO, Néstor Raúl Correa. El proceso constituyente: el caso colombiano. Revista Facultad de Derecho y Ciencias Politicas, Medellín, n. 91, p. 23-38, 1990.

74 GUEVARA, Andrés Dávila Ladrón de. Democracia pactada: el Frente Nacional y el proceso constituyente de 1991 en Colombia. Lima: Institut Français D'études Andines, 2002.
} 
humanos, bem como a aplicação das teorias jurídicas contemporâneas, a respeito do crime ser um fato típico, ilícito e culpável:

Mas esta é uma sociedade hipócrita, esta é uma sociedade anticristã, que quando se fala ou quando se cometem delitos, certas pessoas se insensibilizam, não reagem, não se comovem, é uma sociedade anticristã, se os mortos forem os delinquentes sem justa causa, se forem os anciãos, se forem os mendigos, se forem os homossexuais, se forem as prostitutas, se forem os anistiados, se forem os que pertencem aos movimentos políticos de esquerda ou de oposição, a sociedade se insensibiliza e por isso temos a criminalidade que temos neste momento, por isso um grande criminólogo Lasañe (sic) dizia que cada sociedade tem a criminalidade que merece e nos disseram em uma administração passada de más recordações para os colombianos, dissimulavam, dissimulavam os crimes, as violações de direitos humanos, com o argumento infame e miserável de que, se havia violações de direitos humanos por parte das autoridades, os delinquentes também violavam, como se a Declaração Universal dos Direitos Humanos e os pactos internacionais e políticos tivessem sido escritos como código moral para os particulares, quando, na verdade, eram exclusivos para os governos e para as autoridades ${ }^{75}$. (Grifo nosso).

Assim, o constituinte denuncia a visão que considera os homossexuais como uma categoria inferior, levando à negação do seu status de sujeitos de direitos humanos. O debate subsequente não abordou tal apontamento, limitando-se às discussões relativas à Procuraduría General de la Nación e à Defensoría de los Derechos, uma vez que suas respectivas regulamentações constituíam o objeto central do debate.

A segunda ocorrência trata da possibilidade de se reconhecer o casamento homoafetivo, conforme citação integral da fala proferida por um constituinte:

Senhor Presidente, não sei como tratar este assunto, mas creio que devo tratar agora porque mais tarde facilmente pode ser dito que não posso sustentar nada verbalmente, como acabamos de aprovar algo em que vejo uma inconsistência, vejo um assunto que pode ser delicado, no artigo 24 que acabam de distribuir diz toda pessoa tem o direito de formar livremente uma família, eu não sei que frase, por não ter o resto do artigo à mão, se substitui o projeto que foi apresentado pela Quinta Comissão sobre direitos da família e que é fundamentalmente diferente, não sei se substitui porque fala da constituição de uma família e o fato de aprovar o artigo 24, o fato de aprovar... eu considero que há necessidade de falar desse tema porque não se pode ocultar a primeira frase de um artigo que pode vir depois, ou poderia ter desaparecido o artigo, Senhor Presidente, desculpe-me, Senhor Presidente, mas não creio que seja prudente, sem conhecer o texto completo votar esse artigo que permite a constituição de famílias homossexuais, desculpe-me mas deve ser falado assim com clareza. ${ }^{76}$ (Grifo nosso).

\footnotetext{
75 No original: "Pero es que esta es una sociedad hipócrita, esta es una sociedad anticristiana, que cuando se habla o cuando se cometen delitos, en ciertas personas se insensibiliza, no reacciona, no se conmueve, es una sociedad anticristiana, si los muertos fueron los delincuentes sin justa causa, si fueron los ancianos, si fueron los mendigos, si fueron los homosexuales, si fueron las prostitutas, si fueron los amnistiados, si fueron los que pertenecen a movimientos políticos de izquierda o de oposición, la sociedad se insensibiliza y por eso es por lo que tenemos la criminalidad que tenemos hoy en este momento, por eso un gran criminólogo Lasañe (sic) decía que cada sociedad tiene la criminalidad que se merece y entonces nos dijeron en una administración pasada de ingrato recuerdo para los colombianos, disimulaban, disimulaban los crímenes, las violaciones de los derechos humanos, con el argumento infame y miserable que es que si de parte de las autoridades había violación de los derechos humanos los delincuentes también los violaban, como si la Declaración Universal de los Derechos Humanos y los pactos internacionales y políticos hubieran sido escritos como código moral para los particulares, cuando lo cierto fué, que fué exclusivamente para los gobiernos y para las autoridades". COLÔMBIA. Asamblea Nacional Constituyente. Informe de la sesión de la plenaria del día 3 de junio de 1991. Bogotá: Asamblea Nacional Constituyente, 1991. p. 33-34. Disponível em: http://babel.banrepcultural.org/cdm/singleitem/collection/p17054coll28/id/158/rec/224. Acesso em: 05 abr. 2019. 76 No original: "Señor Presidente, no sé cómo tratar este asunto, pero creo que debo tratarlo ya porque más tarde fácilmente se me puede decir que no puede sustenterse verbalmente nada, según acabamos de aprobar resulta que veo una inconsistencia veo un asunto que puede ser delicado, en el Artículo 24 que acaban de distribuir dice toda persona tiene derecho a formar libremente una familia, esa frase no sé, por no tener el resto del articulado a la mano si reemplaza el proyecto que fue presentado por la Comisión Quinta sobre derechos de la familia y que es fundamentalmente diferente, no sé si lo reemplaza porque habla de la Constitución de una familia y el hecho de aprobar el artículo 24, el hecho de aprobar .. sí yo considero que hay necesidad de hablar de este tema porque no se puede ocultar que es una primera frase de un artículo que puede venir después, o pudo haber desaparecido el artículo y además Señor Presidente, excúseme Señor Presidente pero yo no creo que sea prudente, sin conocer el articulado completo votar este artículo que permite la constitución de familias entre homosexuales, excúseme pero debe hablarse así con claridad". COLÔMBIA. Asamblea Nacional Constituyente. Informe de la sesión de la plenaria del día 28 de junio de 1991. Bogotá: Asamblea Nacional Constituyente, 1991. p. 86. Disponível em: http://babel.banrepcultural.org/cdm/singleitem/collection/p17054coll28/id/52/rec/219. Acesso em: 05 abr. 2019.
} 
Como se pode perceber, a fala não se refere a uma discussão que estava sendo realizada naquele momento. Consistiu, na verdade, na vontade de o constituinte esclarecer um dispositivo antes do fim do prazo para alterações. Com isso, a sua fala não suscitou um debate, visto que outras questões estavam sendo resolvidas. Mais tarde, no mesmo dia, outro membro da ANCC tentou elucidar o assunto:

[...] a preocupação do doutor Benitez foi uma preocupação da Quinta Comissão, que, ao estabelecer a liberdade para formar família sem especificar qual o tipo, pode ser interpretado que qualquer gênero de família pode ser formado, creio que o critério da Comissão Codificadora foi não restringir esse conceito, eu fiz a advertência de que na Quinta Comissão havíamos feito algumas observações sobre isso, e a intenção foi saudável, foi não amarrar a família somente ao caso do matrimônio, porque existem famílias de pais e filhos, há família com filhos adotivos, há famílias que se formam de outras maneiras, então... ${ }^{77}$.

Tal assunto foi retomado na última ocorrência encontrada, referente ao dia 29 de junho de 1991.

[...] artigo 43, toda pessoa tem direito de forma livremente uma família. Primeiro, a família é o núcleo fundamental da sociedade e se constitui por vínculos jurídicos ou naturais. Segundo, o Estado garante a proteção integral da família, a lei poderá estabelecer o patrimônio familiar inalienável e impenhorável. Terceiro, as relações familiares se fundamentam no mútuo respeito, na igualdade entre os cônjuges e na identidade de direitos e deveres dos pais em relação aos filhos.

\section{$[\ldots]$}

— Faço uma pergunta simplesmente. Ouvi que essa substitutiva começa com uma frase que já foi retirada pelo próprio doutor Augusto Ramírez Ocampo, então.

— Sim, eu vejo muita contradição, doutor Augusto.

- Estou confuso, porque primeiro foi retirado, que é algo que tem alguma relação com o homossexualismo e agora reaparece a mesma frase, não sei como será.

- Vamos ver, vamos ver.

— Senhor Presidente, então os proponentes a eliminam?

— Não tem nada a ver com homossexualismo, honorável Delegada.

— Sobre votação, somente votação.

- Observar que falta o essencial, que é a expressão um homem e uma mulher. Obrigado, senhor Presidente ${ }^{78}$. (Grifo nosso).

Dessa forma, verifica-se que houve um esforço em garantir que a instituição do casamento não fosse aplicável a casais homossexuais. A intenção era retirar a vagueza do dispositivo constitucional, pois, a prin-

\footnotetext{
77 No original: "ahora bien la preocupación del doctor Benitez fue una preocupación de la Comisión Quinta, que al establecer la libertad para formar familia sin especificar qué tipo de familia puede interpretarse que puede formarse cualquier género de familia, creo que el criterio de la Comisión Codificadora fue no restringir ese concepto, yo hice la advertencia de que ya en la Comisión Quinta habíamos hecho algunas observaciones sobre eso, y la intención fue sana, fue no amarrar la familia solamente en el caso del matrimonio, porque hay familia de padres e hijos hay familia con hijos adoptivos, hay familias que se forman de otras maneras, entonces...”. COLÔMBIA. Asamblea Nacional Constituyente. Informe de la sesión de la plenaria del día 28 de junio de 1991. Bogotá: Asamblea Nacional Constituyente, 1991. p. 150. Disponível em: http://babel.banrepcultural.org/cdm/singleitem/collection/ p17054coll28/id/52/rec/219. Acesso em: 05 abr. 2019.

78 No original: "artículo 43, toda persona tiene derecho de formar libremente una familia. Primero la familia es el núcleo fundamental de la sociedad y se constituye por vínculos jurídicos o naturales Segundo, el Estado garantiza la protección integral de la familia, la ley podrá establecer el patrimonio familiar inalienable e inembargable. Tercero, las relaciones familiares se fundamentan en el mutuo respeto, en la igualdad entre los cónyuges y en la identidad de derechos y deberes de los padres en relación a los hijos. [...] - Hago una pregunta simplemente. Oí que esa sustitutiva, empieza con una frase que ya fue retirada por el mismo doctor Augusto Ramírez Ocampo, entonces. - Si, yo veo mucha contradicción doctor Augusto - Estoy confundido, porque primero la retiró, que es algo que tiene alguna relación con el homosexualismo, y ahora vuelve a aparecer la misma frase no sé qué será. - A ver, a ver. -Señor Presidente ¿Entonces la eliminan los proponentes? - No tiene nada que ver con el homosexualismo, Honorable Delegada. - Sobre votación, sólo votación - Para observar que ahí falta lo esencial, que es la expresión un hombre y una mujer gracias Señor Presidente". COLÔMBIA. Asamblea Nacional Constituyente. Informe de la sesión de la plenaria del día 29 de junio de 1991. Bogotá: Asamblea Nacional Constituyente, 1991. p. 59-61. Disponível em: http://babel.banrepcultural.org/cdm/singleitem/collection/ p17054coll28/id/85/rec/221. Acesso em: 05 abr. 2019.
} 
cípio, toda pessoa possuía direito de formar livremente uma família. Em razão disso, a redação final foi a seguinte:

Artigo 42. A família é o núcleo fundamental da sociedade. Constitui-se por vínculos naturais ou jurídicos, pela decisão livre de um homem e uma mulher de contrair matrimônio ou pela vontade responsável de conformá-la. ${ }^{79}$

O texto promulgado da Constituição Colombiana solucionou a indeterminação anterior, de modo que a família ficou restrita à união entre um homem e uma mulher. Contudo, apesar dessa delimitação, tal conceito de família recebeu diversas interpretações por parte da Corte Constitucional Colombiana. A tendência é ampliá-lo para que outras formas de vida em comum possam ter direitos inicialmente exclusivos da instituição familiar ${ }^{80}$.

Tendo em vista o reduzido número de ocorrências e o baixo desenvolvimento dos debates, não há como estabelecer categorias argumentativas como foi feito na análise da Constituinte brasileira. Ainda assim, podem ser traçadas algumas conclusões acerca da ANCC.

Primeiramente, com relação aos direitos LGBTI, registra-se a existência de argumentos positivos, caracterizados por serem, apenas, uma defesa geral e superficial, e negativos, cuja justificação não é possível de ser depreendida. Em segundo, verifica-se como o debate fica limitado ao casamento homoafetivo, não sendo abordados outros direitos LGBTI, tampouco foi discutida a possibilidade de vedação da discriminação por orientação sexual ou identidade de gênero. Por fim, foi possível perceber como as referências feitas pelos constituintes eram, apenas, aos homossexuais, isto é, a orientação sexual foi inserida no debate, enquanto a identidade de gênero permaneceu invisibilizada.

Nesse sentido, Claudia Caycedo ${ }^{81}$ aponta uma "etnização" do conteúdo da diversidade, de modo que, durante a ANCC, as discussões acerca desse assunto ficaram restritas aos aspectos étnicos, com preponderância para a população indígena. Assim, além da população LGBTI, outros grupos minoritários, como mulheres e negros, não receberam a devida atenção durante os debates constituintes.

Por fim, destaca-se, tal como apontado por Ochy Curiel, a partir da sua análise da ANCC, que há uma predominância de homens com privilégios de classe, raça e sexualidade, fazendo com que a Constituição seja moldada com base na heteronação.

\section{Considerações finais}

O estudo dos processos de elaboração de uma nova constituição tem um importante papel histórico, pois revela a dinâmica existente entre as forças políticas atuantes. Com isso, é possível compreender determinadas escolhas que foram incorporadas no texto constitucional e que, a partir de então, passam a nortear todo o ordenamento jurídico.

Como foi possível perceber, as Assembleias Constituintes brasileira e colombiana foram compostas por indivíduos que não contemplavam a pluralidade de suas respectivas populações, de forma que o pacto constitucional foi construído, majoritariamente, por grupos hegemônicos. Consequentemente, a diversidade foi

\footnotetext{
79 No original: "Artículo 42. La familia es el núcleo fundamental de la sociedad. Se constituye por vínculos naturales o jurídicos, por la decisión libre de un hombre y una mujer de contraer matrimonio o por la voluntad responsable de conformarla". COLÔMBIA. Constitución Politica de Colombia. 1991. Disponível em: http://www.corteconstitucional.gov.co/inicio/Constitucion $\% 20$ politica $\% 20$ de\%20Colombia.pdf. Acesso em: 10 maio 2019.

80 CAMARGO, Rosa Elizabeth Guío. El concepto de familia en la legislación y en la jurisprudencia de la Corte Constitucional colombiana. Studiositas, Bogotá, v. 4, n. 3, p. 65-81, dez. 2009.

81 CAYCEDO, Claudia Hurtado. La marcha LGBT: para ampliar el canon de la ciudadanía con las diversidades sexuales. 2010. Dissertação (Mestrado em Estudios Culturales) - Facultad de Ciencias Sociales, Pontificia Universidad Javeriana, Bogotá, 2010. p. 29.
} 
restringida, mas, mesmo assim, foi pressuposta a representação de setores alijados desse processo.

No Brasil, os direitos LGBTI foram objeto de discussão, recebendo tanto argumentos positivos quanto negativos. Com relação aos primeiros, foram identificadas defesas gerais de grupos oprimidos e outras voltadas, especificamente, para a população LGBTI. No que tange aos argumentos negativos, em razão da sua expressividade numérica, foram divididos em três categorias: base religiosa; repugnância; e consequencialismo falacioso.

$\mathrm{Na}$ Colômbia, por sua vez, o debate acerca dos direitos LGBTI se deu apenas de forma incidental. Foram feitas menções à população, contudo a maioria teve uma conotação negativa, visto que se buscava garantir que o matrimônio não seria aplicável a casais homossexuais.

Apesar das diferenças, ambos os casos guardam uma semelhança: a ausência de pessoas abertamente LGBTI no corpo constituinte. Esse fato explica a limitação dos debates e, por conseguinte, a não previsão de direitos específicos nos textos constitucionais, que se alicerçam na ideia de heteronação.

Desse modo, os problemas inicialmente levantados encontram duas respostas possíveis. Em primeiro lugar, a falta de representatividade LGBTI nas Assembleias Constituintes, em suas facetas descritiva e substantiva, pode ter sido um fator determinante para a ausência de previsão de direitos específicos. Por outro lado, e ainda diretamente conectado à razão anterior, o tratamento dado à temática LGBTI demonstrou grande desconhecimento da matéria pelos constituintes. Nesse sentido, identificou-se, também, que os principais posicionamentos contrários à positivação desses direitos se embasavam em argumentos de moralidade, na maioria dos casos ligados a tradições religiosas, externalizando discursos extremamente homofóbicos e transfóbicos por parte dos constituintes.

Sendo assim, concluiu-se que, mais uma vez, o preconceito histórico existente contra a população LGBTI impediu não somente a sua integração e participação efetiva nos processos constituintes, mas também serviu de suporte à sua completa exclusão dos novos textos constitucionais. Assim, reforça-se a necessidade de políticas de combate à discriminação contra pessoas LGBTI que extrapolem o campo jurídico e trabalhem, desde cedo, a eliminação do preconceito por políticas públicas multidisciplinares, voltando-se, principalmente, para a educação.

\section{Referências}

AVRITZER, Leonardo. O novo constitucionalismo latino-americano: uma abordagem política. In: AVRITZER, Leonardo et al. O constitucionalismo democrático latino-americano em debate: soberania, separação de poderes e sistema de direitos. Belo Horizonte: Autêntica, 2017. p. 19-42.

BARROSO, Luís Roberto. Judicialização, ativismo judicial e legitimidade democrática. (Syn)Thesis, Rio de Janeiro, v. 5, p. 23-32, 2012. Disponível em: https://www.e-publicacoes.uerj.br/index.php/synthesis/article/ view/7433. Acesso em: 15 mar. 2019.

BELLO, Enzo. O pensamento descolonial e o modelo de cidadania do novo constitucionalismo latinoamericano. Revista de Estudos Constitucionais, Hermenêutica e Teoria do Direito (RECHTD), São Leopoldo, v. 7, n. 1, p. 49-61, jan./abr. 2015. Disponível em: http://revistas.unisinos.br/index.php/RECHTD/article/view/ rechtd.2015.71.05. Acesso em: 21 fev. 2019.

BRASIL. Anais da Assembleia Nacional Constituinte. Disponível em: https://www.senado.leg.br/publicacoes/ anais/asp/CT_Abertura.asp

CAMARGO, Rosa Elizabeth Guío. El concepto de familia en la legislación y en la jurisprudencia de la Corte Constitucional colombiana. Studiositas, Bogotá, v. 4, n. 3, p. 65-81, dez. 2009. Disponível em: https://re- 
pository.ucatolica.edu.co/bitstream/10983/573/1/Stud_4-3_A07_guio-camargo-.pdf. Acesso em: 24 maio 2019.

CAMARGO, Sergio Roberto Matias. La Asamblea Nacional Constituyente de 1991 y el Nuevo Constitucionalismo Latinoamericano. Dialógos des saberes, Bogotá, n. 44, p. 29-44, ene./jun. 2016. Disponível em: https://dialnet.unirioja.es/servlet/articulo?codigo=5823638. Acesso em: 08 maio 2019.

CARDANO, Mario. Manual de pesquisa qualitativa: a contribuição da teoria da argumentação. Petrópolis: Vozes, 2017.

CAYCEDO, Claudia Hurtado. La marcha LGBT: para ampliar el canon de la ciudadanía con las diversidades sexuales. 2010. Dissertação (Mestrado em Estudios Culturales) - Facultad de Ciencias Sociales, Pontificia Universidad Javeriana, Bogotá, 2010.

COLÔMBIA. Asamblea Nacional Constituyente. Informe de la sesión de la plenaria del día 28 de junio de 1991. Bogotá: Asamblea Nacional Constituyente, 1991. Disponível em: http://babel.banrepcultural.org/cdm/ singleitem/collection/p17054coll28/id/52/rec/219. Acesso em: 05 abr. 2019.

COLÔMBIA. Asamblea Nacional Constituyente. Informe de la sesión de la plenaria del día 29 de junio de 1991. Bogotá: Asamblea Nacional Constituyente, 1991. Disponível em: http://babel.banrepcultural.org/cdm/ singleitem/collection/p17054coll28/id/85/rec/221. Acesso em: 05 abr. 2019.

COLÔMBIA. Asamblea Nacional Constituyente. Informe de la sesión de la plenaria del día 3 de junio de 1991. Bogotá: Asamblea Nacional Constituyente, 1991. Disponível em: http://babel.banrepcultural.org/cdm/ singleitem/collection/p17054coll28/id/158/rec/224. Acesso em: 05 abr. 2019.

COLÔMBIA. Constitución Politica de Colombia. 1991. Disponível em: http://www.corteconstitucional.gov.co/ inicio/Constitucion\%20politica\%20de\%20Colombia.pdf. Acesso em: 10 maio 2019.

CORRALES, Javier. LGBT rights and representation in Latin America and the Caribbean: the influence of structure, movements, institutions, and culture. University of North Carolina: LGBT Representation and Rights Initiative, 2015. Disponível em: https://globalstudies.unc.edu/files/2015/04/LGBT_Report_LatAm_v8copy.pdf. Acesso em: 10 jan. 2019.

CORRALES, Javier. Understanding the uneven spread of LGBT rights in Latin America and the Caribbean, 1999-2013. Journal of Research in Gender Studies, New York, v. 7, n. 1, p. 52-82, 2017. Disponível em: https:/ /addletonacademicpublishers.com/contents-jrgs/990-volume-7-1-2017/2968-understanding-theuneven-spread-of-lgbt-rights-in-latin-america-and-the-caribbean-1999-2013. Acesso em: 20 nov. 2018.

CURIEL, Ochy. La nación heterosexual: análisis del discurso jurídico y el régimen heterosexual desde la antropología de la dominación. Bogotá: Impresol Ediciones, 2013.

FACCHINI, Regina. Sopa de letrinhas? Movimento homossexual e produção de identidades coletivas nos anos 1990. Rio de Janeiro: Garamond, 2005.

FAJARDO, Raquel Z. Yrigoyen. El horizonte del constitucionalismo pluralista: del multiculturalismo a la decolonización. In: GARAVITO, César Rodríguez (coord.). El derecho en América Latina: un mapa para el pensamento jurídico del siglo XXI. Buenos Aires: Siglo Veintiuno Editores, 2011. p. 139-159.

FRASER, Nancy. Reenquadrando a justiça em um mundo globalizado. Lua Nova, São Paulo, v. 77, p. 11-39, 2009. Disponível em: http://www.scielo.br/pdf/ln/n77/a01n77.pdf. Acesso em: 15 jun. 2019.

GARGARELLA, Roberto. Latin american constitutionalism: social rights and the "Engine Room" of the Constitution. Notre Dame Journal of International and Comparative Law, Notre Dame, v. 4, n. 1, p. 8-18, 2014. Disponível em: https://scholarship.law.nd.edu/ndjicl/vol4/iss1/3/. Acesso em: 30 out. 2018.

GRAMSCI, Antonio. El materialism histórico y la filosofia de Benedetto Croce. México: Juan Pablo Editor, 1975. 
GUEVARA, Andrés Dávila Ladrón de. Democracia pactada: el Frente Nacional y el proceso constituyente de 1991 en Colombia. Lima: Institut Français D'études Andines, 2002.

HENAO, Néstor Raúl Correa. El proceso constituyente: el caso colombiano. Revista Facultad de Derecho y Ciencias Politicas, Medellín, n. 91, p. 23-38, 1990. Disponível em: https://dialnet.unirioja.es/servlet/ articulo?codigo $=5568206$. Acesso em: 09 maio 2019.

JESUS, Jaqueline Gomes de. Transfobia e crimes de ódio: assassinatos de pessoas transgênero como genocídio. In: MARANHÃO, F.; ALBUQUERQUE, Eduardo Meinberg de (orgs.). (In)visibilidade trans 2: história agora, v. 16, n. 2, p. 101-123, 2013. Disponível em: https://www.researchgate.net/publication/281321251_ Transfobia_e_crimes_de_odio_Assassinatos_de_pessoas_transgenero_como_genocidio. Acesso em: 20 maio 2019.

KING, Nigel. Doing template analysis. In: SYMON, Gillian; CASSEL, Catherine. Qualitative methods in organizational research: core methods and current challenges. London: Sage Publications, 2012. p. 426-450.

LELIS, Rafael Carrano. Em busca das cores latino-americanas: uma análise da proteção constitucional dos direitos LGBTIs na América Latina. Rio de Janeiro: Lumen Juris, 2018.

MAGALHÃES, José Luiz Quadros de. O novo constitucionalismo democrático na América Latina. Revista Vox, Reduto, v. 01, p. 01-14, jan./jun. 2015. Disponível em: http://www.fadileste.edu.br/revistavox/ojs2.4.8/index.php/revistavox/article/view/72. Acesso em: 25 fev. 2019.

MAGALHÃES, José Luiz Quadros de. O novo constitucionalismo latino-americano 2: rupturas - diversidade. Revista Eletrônica de Direito do Centro Universitário Nenton Paiva, Belo Horizonte, n. 28, p. 10-19, jan./abr. 2016. Disponível em: http://blog.newtonpaiva.br/direito/wp-content/uploads/2016/02/DIR-28-01.pdf. Acesso em: 25 fev. 2019.

NUSSBAUM, Martha C. From disgust to bumanity: sexual orientation and constitutional law. New York: Oxford University Press, 2010.

PASTOR, Roberto Viciano; DALMAU, Rubén Martínez. ¿Se puede hablar de un nuevo constitucionalismo latinoamericano como corriente doctrinal siste- matizada? Valencia: Universidad de Valencia, 2010. Disponível em: http:// www.ufjf.br/siddharta_legale/files/2014/07/Rube\%C2\%A6\%C3\%BCn-Marti\%C2\%A6\%C3\%BCnezDalmau.-Se-puede-hablar-de-un-nuevo-constitucionalismo-latinoamericano-como-corrente-doctrinal-sistematizada.pdf. Acesso em: 30 mar. 2019.

PASTOR, Roberto Viciano; DALMAU, Rubén Martínez. Presentación: aspectos generales del nuevo constitucionalismo latinoamericano. In: CORTE CONSTITUCIONAL DE ECUADOR PARA EL PERÍODO DE TRANSICIÓN. El nuevo constitucionalismo en América Latina: memorias del encuentro internacional El nuevo constitucionalismo: desafíos y retos para el siglo XXI. Quito: Corte Constitucional del Ecuador, 2010. p. 09-44. Disponível em: https://mestrado.direito.ufg.br/up/14/o/34272355-Nuevo-Constitucionalismo-en-America-Latina.pdf?1352144011. Acesso em: 30 mar. 2019.

PASTOR, Roberto Viciano; DALMAU, Rubén Martínez. Los procesos constituyentes latinoamericanos y el nuevo paradigma constitucional. Revista del Instituto de Ciencias Jurídicas de Puebla, Puebla, v. 25, p. 7-29, 2010. Disponível em: http://www.redalyc.org/pdf/2932/293222977001.pdf. Acesso em: 30 mar. 2019.

PASTOR, Roberto Viciano; DALMAU, Rubén Martínez. Fundamentos teóricos y prácticos del nuevo constitucionalismo latinoamericano. Gaceta Constitucional, v. 48, p. 307-328, 2011.

PILATTI, Adriano. A Constituinte de 1987-1988: progressistas, conservadores, ordem econômica e regras do jogo. Rio de Janeiro: Lumen Juris, 2016.

REYNOLDS, Andrew. Representation and rights: the impact of LGBT legislators in comparative perspective. American Political Science Review, Cambridge, v. 107, n. 02, p. 259-274, 2013. Disponível em: https://www. 
cambridge.org/core/journals/american-political-science-review/article/representation-and-rights-the-impact-of-lgbt-legislators-in-comparative-perspective/E24FDB19C4F65129822660667C8442D2. Acesso em: 19 jan. 2019.

RUBIN, Gayle. Políticas do sexo. São Paulo: Ubu Editora, 2017.

SANTOS, Boaventura de Souza. Refundación delEstado en América Latina: perspectivas desde una epistemología del sur. Lima: Instituto Internacional de Derecho y Sociedad, 2010.

SILVA, José Afonso da. Um pouco de direito constitucional comparado. São Paulo: Malheiros, 2009.

SIMÕES, Júlio Assis; FACCHINI, Regina. Na trilha do arco-íris: do movimento homossexual ao LGBT. São Paulo: Editora Fundação Perseu Abramo, 2009.

STRECK, Lenio Luiz; OLIVEIRA, Fábio Corrêa Souza de. Reflexões sobre o novo constitucionalismo latino-americano. In: SANTOS, Gustavo Ferreira; STRECK, Lenio Luiz; ARAÚJO, Marcelo Labanca Corrêa de (orgs.). Direitos e democracia no novo constitucionalismo latino-americano. Belo Horizonte: Arraes Editores, 2016. p. 119-144.

TEIXEIRA, João Paulo Allain. Direitos fundamentais e constituição: as respostas do neoconstitucionalismo europeu e do novo constitucionalismo latino-americano. In: SANTOS, Gustavo Ferreira; STRECK, Lenio Luiz; ARAÚJO, Marcelo Labanca Corrêa de (orgs.). Direitos e democracia no novo constitucionalismo latino-americano. Belo Horizonte: Arraes Editores, 2016. p. 45-51.

VICENTE, Dário Moura. Direito comparado. Coimbra: Almedina, 2016.

VIEIRA, José Ribas et al. Impasses e alternativas em 200 anos de constitucionalismo latino-americano. Revista de Estudos Constitucionais, Hermenêtica e Teoria do Direito (RECHTD), São Leopoldo, v. 5, n. 2, p. 122-132, jul./dez. 2013. Disponível em: http://revistas.unisinos.br/index.php/RECHTD/article/view/ rechtd.2013.52.04. Acesso em: 30 mar. 2019.

VITAL, Christina; LOPES, Paulo Victor Leite. Religião e política: uma análise da atuação dos parlamentares evangélicos sobre direitos das mulheres e de LGBTs no Brasil. Rio de Janeiro: Fundação Heinrich Böll, 2012. Disponível em: https://br.boell.org/sites/default/files/publicacao_religiao_e_politica_chris_vital_e_paulo_victor_14mar_webfinal.pdf. Acesso em: 20 nov. 2018.

WEEKS, Jeffrey. Sex, politics and society: the regulation of sexuality since 1800. London: New York: Routledge, 2012.

WITTIG, Monique. El pensamento heterosexual y otros ensayos. Barcelona: Egales, 2006. 
Para publicar na revista Brasileira de Políticas Públicas, acesse o endereço eletrônico www.rbpp.uniceub.br

Observe as normas de publicação, para facilitar e agilizar o trabalho de edição. 